\title{
$\mathrm{C}|\mathrm{E}| \mathrm{D}|\mathrm{L}| \mathrm{A} \mid \mathrm{S}$
}

Centro de Estudios

Distributivos, Laborales y Sociales

Maestría en Economía

Universidad Nacional de La Plata

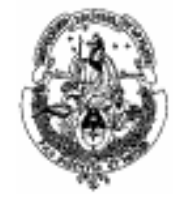

\section{Housing, Health and Happiness}

\section{Matias D. Cattaneo, Sebastian Galiani, Paul J. Gertler, Sebastian Martinez y Rocio Titiunik}

Documento de Trabajo Nro. 74

Agosto, 2008 


\title{
Housing, Health and Happiness
}

\author{
Matias D. Cattaneo, Sebastian Galiani, Paul J. Gertler, Sebastian Martinez and \\ ROCIO TITIUNIK*
}

July 12, 2008

\begin{abstract}
Despite the importance of housing for people's well-being, there is little evidence on the causal impact of housing and housing improvement programs on health and welfare. In this paper, we help to fill this gap by investigating the impact of a large-scale effort by the Mexican Government to replace dirt floors with cement floors on child health and adult happiness. We find that replacing dirt floors with cement floors significantly improves the health of young children. Specifically, we find significant decreases in the incidence of parasitic infestations, diarrhea, and the prevalence of anemia, and an improvement in children's cognitive development. Additionally, we find that replacing dirt floors by cement floors significantly improves adult welfare, as measured by increased satisfaction with their housing and quality of life, as well as by lower scores on depression and perceived stress scales. (JEL: I12, I38 and H43)
\end{abstract}

Housing, food and water are considered to be basic requirements for daily living. Unfortunately, inadequate housing with poor water supply, sanitation, and ventilation threatens the lives and health of some 600 million urban dwellers worldwide (see, among others, Cebu Study Team (1991), S. A. Esrey, et al. (1991), Sebastian Galiani, Paul J. Gertler and Ernesto Schargrodsky (2005), and World Bank (2005)). For this reason, most countries in the world devote substantial resources to upgrading slum areas and improving housing quality for poor groups in the population. For example, the U.S. Government spends more on housing programs than on other better-known welfare programs, such as food stamps and temporary assistance for needy families (Edgar O. Olsen (2003)). In the developing world, where urbanization is strongly associated with the rapid spread of slums, and where slum dwellers account for 45 percent of the urban population, policies to improve the welfare of slum dwellers focus on such areas as

\footnotetext{
*Cattaneo: Department of Economics, University of Michigan, Ann Arbor, MI 48109 (email: cattaneo@umich.edu); Galiani: Department of Economics, Washington University in St. Louis, St. Louis, MO 63130 (email: galiani@wustl.edu); Gertler: Haas Business School, University of California, Berkeley 94720 (email: gertler@haas.berkeley.edu); Martinez: World Bank, Washington, DC 20433 (email: smartinez@worldbank.org); Titiunik: Department of Agricultural and Resource Economics, University of California, Berkeley 94720 (email: titiunik@berkeley.edu). We thank Albert Fishlow, Larry Katz, Ted Miguel, Norbert Schady, Jennifer Sturdy, two anonymous referees, and seminar participants at Columbia, Michigan, Berkeley, Toulouse and World Bank for useful comments. We gratefully acknowledge support from the State of Coahuila, and thank Gonzalo Hernandez, Enrique Martinez y Morales, Ricardo Mujica and Gustavo Olaiz, and the Government of the State of Coahuila for their contribution to our understanding of the program and for helping us with our work in Mexico. S. Galiani thanks the hospitality of the Stanford Institute for Economic Policy Research while he was revising this paper.
} 
upgrading slum housing in situ and relocating slum dwellers to better-quality, low-cost housing (World Bank (2005)). Despite the importance of housing as a factor influencing well-being, little work has been done to assess the causal impact of housing and housing improvement programs on health and welfare.

In this paper, we examine one particular aspect of housing, floor quality, and its impact on the health of young children, as well as the mental health and happiness of their mothers. Specifically, we examine a large-scale effort by the Mexican Government to replace dirt floors with cement floors as a means of identifying the impact of cement floors on child health and maternal happiness. The program, called Piso Firme, offered households with dirt floors up to 50 square meters (538 square feet) of concrete cement flooring.

In order to identify the effects of this intervention on child health and development, as well as maternal happiness outcomes, we take

advantage of the geographic variability in the implementation of the program. Piso Firme was first implemented as a local program in the State of Coahuila. The program was later adopted nationally and gradually extended to other states. In principle, we could compare beneficiary families in the State of Coahuila to families in the neighboring states that had not yet implemented Piso Firme.

While this provides us with an administrative source of variability in treatment exposure among households across states, we are not guaranteed that the outcomes of interest would be on average the same in these two states in the absence of the intervention. We take several steps to improve the comparability of the treatment and control groups. First, we restrict our analysis exclusively to the contrast of the outcomes of interest between families residing in the twin cities of Gómez Palacios/Lerdo (control) and Torreón (treatment) that straddle the border of the States of Durango and Coahuila, respectively. Although these cities are split administratively between the two states, they are effectively a single urban area in socio-economic terms. Therefore, households residing in this area face the same socio-economic circumstances as well as a similar cultural and natural environment. Consequently, households residing near the border in these cities are likely to be similar except for the influence of state policies. Second, we further improve the comparability of the treatment and control groups by sampling from census blocks in the control area that best match the census blocks from the treatment area using preintervention information from the 2000 national census.

Thus, to the extent that the only important difference in state policies is Piso Firme, we can estimate its impact on the outcomes of interest for households residing near the state border in the city of Torreón, using the households from Gómez Palacio/Lerdo as a control group. In order to provide evidence in support of this identification strategy, we show that treatment and control areas had very similar secular health and socio-economic environments both before and after the State of Coahuila implemented Piso Firme.

We find that Piso Firme significantly increased the share of cement floors and child health among treated households. Specifically, we find significant decreases in the incidence of parasitic infestations, diarrhea, and the prevalence of anemia as well as a significant improvement in the cognitive development of treated children.

The improvement in cognitive development of young children is very important, as research in neuroscience, psychology and cognition has established that learning is easier in early childhood than later in life and that it is critical for school readiness and long-term skill development (see, among others, John D. Bransford (1979), Robert J. Sternberg (1985), Rima Shore (1997) and Jack P. Shonkoff and Deborah A. Phillips (2000)). Gary S. Becker (1964) 
points out that the returns to investments made in early childhood are likely to be higher than they are for investments made later in life simply because beneficiaries have a longer time to reap the rewards. Pedro Carneiro and James J. Heckman (2003) and James J. Heckman and Dimitriy V. Masterov (2007) note that investments in human capital have dynamic complementarities, so that "learning begets learning." Additionally, poor cognitive development affects school enrollment and learning and, consequently, also influences lifetime earnings and welfare (see, among others, Jere R. Behrman (1996)).

These results are important inputs into public resource allocation decisions regarding efforts to improve child development outcomes. Piso Firme is more cost-effective and has a comparable absolute impact on child cognitive development when compared to Mexico's anti-poverty conditional cash transfer program, OPORTUNIDADES -formerly called PROGRESA (Paul J. Gertler (2004), Juan A. Rivera, et al. (2004) and Lia C. H. Fernald, Paul J. Gertler, Lynnette M. Neufeld (2008)). Our results also indicate that replacing dirt floors with cement floors appears to be more cost-effective than nutritional supplementation and early childhood cognitive stimulation (Patrice L. Engle, et al. (2007)).

We also find that, following the implementation of the program, adults are substantially happier, as measured by their degree of satisfaction with their housing and quality of life, and have significantly lower scores on depression and perceived stress assessment tools. The reasons why adults are happier may have to do both with the fact that they are living in a better environment and with the fact that their children are healthier. These results also indicate that housing has a significant effect on welfare, which would not be captured by standard monetary indicators such as income, consumption or assets, or by the types of health outcomes used in this study.

Our results contribute to a small body of literature on the benefits of slum upgrading. There are a large number of papers in the medical literature that document associations between housing and health. In a critical survey of this literature, Hilary Thomson, Mark Petticrew and David Morrison (2001) report no randomized or quasi-experimental studies and assert that most of the work in this area consists of cross-sectional associations. The economic literature has focused on the identification of the market value of various housing characteristics (see, among others, Emmanuel Jimenez (1983), Randall Crane, Amrita Daniere and Stacy Harwood (1997), and Kenneth Y. Chay and Michael Greenstone (2005)) or the gain in welfare obtained from housing upgrades as reflected by the compensating variation measured via estimated utility functions (Daniel Kaufmann and John M. Quigley (1987) and Akie Takeuchi, Maureen Cropper and Antonio Bento (2006)). An exception is Lawrence F. Katz, Jeffrey R. Kling and Jeffrey B. Liebman (2001), who examine the impacts of changes in residential neighborhoods on the wellbeing of families residing in high-poverty areas that received housing vouchers through a random lottery in the U.S. They find that households that were offered vouchers experienced improvements in multiple measures of well-being, including improved health among heads of household and a reduction in the likelihood of asthma attacks and injuries among children.

The rest of the paper is organized as follows. In Section I, we present a discussion of the Mexican Piso Firme program and the conceptual framework. In Section II, we outline our identification and sampling strategies. In Section III, we describe the data. In Section IV, we demonstrate that the control and treatment groups are balanced. In Section V we present the program impacts, analyzing the effect of offering Piso Firme on the installation of cement floors, child health and maternal mental health and happiness. In Section VI, we present a series of tests 
to address the robustness of the results to alternative explanations and specifications. Finally, in Section VII we outline our conclusions.

\section{Conceptual Framework}

Piso Firme -which translates into English as "firm floor"- is a program designed to replace dirt floors with cement floors in the homes of low-income families in Mexico. While this type of intervention had been a small sub-component of two Federal programs targeted to rural and indigenous areas, ${ }^{1}$ the first large-scale stand-alone program targeted to both rural areas and urban slums was implemented by the northern State of Coahuila starting in $2000 .^{2}$ Subsequently, starting in late 2003, other states and other federally funded programs adopted Piso Firme., Through these initiatives, by 2005 cement floors were installed in about 300,000 of the estimated 3 million houses that reported dirt floors in the 2000 Mexican census.

Coahuila's Piso Firme grew out of Governor Enrique Martinez y Martinez's (2000-2005) campaign pledge to reduce the prevalence of households with dirt floors in the state. The Coahuila program was developed out of situational assessments conducted by the Martinez electoral campaign prior to his election. The stated objective of Piso Firme was to improve the living standards -especially health- of vulnerable groups that live in high-density low-income neighborhoods (Secretaria de Desarrollo Social de Coahuila (2004)). By 2005, Piso Firme had covered over 34,000 households in 650 neighborhoods and 200 suburban communities in the state, at a cost of approximately \$5.5 million dollars (Secretaria de Desarrollo Social de Coahuila (2005)).

Eligibility for Piso Firme is based on two main factors. First, the household must have dirt floors. Second, the household must prove home ownership prior to receiving Piso Firme. Municipalities identified eligible households and submitted rosters of beneficiaries to the state. The state then validated the municipal proposal, contracted the inputs, and provided oversight for the implementation of the program (Secretaria de Desarrollo Social de Coahuila (2004)). Eligible neighborhoods were surveyed door-to-door and housing units that met these criteria were offered up to 50 square meters (538 square feet) of cement valued at about 1,500 Mexican pesos (approximately 150 US dollars).

State officials reported that almost no one turned down the offer of the program, and that they believed that all of the eligible households were identified and offered the program. In fact,

\footnotetext{
${ }^{1}$ Microregiones, and Comision de Desarrollo de Pueblos Indigenas (CDI) included interventions similar to Piso Firme prior to 2000. The flooring components of these programs were relatively small, and targeted to rural areas with high density of indigenous populations. Microregiones, for example, covered select communities in 6 municipalities in Coahuila and 9 municipalities in Durango in 2003 (http://www.microregiones.gob.mx). These municipalities were not part of our study.

${ }^{2}$ Interviews with Ricardo Mujica, Deputy Director General of Social Program Evaluation, Ministry of Social Development, and Enrique Martinez y Morales, Under-Secretary of Finance in the State of Coahuila, contributed to our better understanding of the origins of Piso Firme in Coahuila.

3 For example, state-level Piso Firme programs have been established in the states of Chihuahua (http://municipios.chihuahua.gob.mx) and Guanajuato (http://leon.gob.mx), and the Piso Firme sub-component of the Programa para Desarrollo Local Microregiones (Program for Local Development Microregiones) has been expanded with the objective of achieving full coverage of cement floors in targeted areas by 2012 (http://www.sedesol.gob.mx).

${ }^{4}$ Interviews with government officials suggest that the subsequent adoption of Piso Firme was in part based on the Coahuila experience as Governor Martinez was a prominent member of the political party in power in Federal government and in part based on situational analyses.
} 
official records of the Coahuila's Piso Firme program confirm that in the aggregate there has been an almost full compliance with the program. The 2000 census registered approximately 4.6 percent or approximately 25,000 households with dirt floors in the State of Coahuila, while approximately 34,000 households had received Piso Firme by 2005 according to the official records.

The program covers the cost of the cement through equal contributions of municipal and state resources. Households supply the labor input needed to prepare and lay the floor. Community volunteers typically assist households that are unable to provide the labor input. Beneficiaries are informed of the delivery date and asked to prepare the rooms following a set of technical specifications. The cement is delivered by large cement trucks that roll through these neighborhoods, spreading the cement house-by-house. Each cement truck carries approximately 7 cubic meters of cement, covering 4 to 5 houses. After the cement is poured, each family smoothes out the floor according to the instructions they received. The entire process is completed within a single day. ${ }^{5}$

The primary objective of the program is to improve standards of living, particularly health, through improvements in the physical environment in which families live. Replacing dirt floors with cement floors improves the cleanliness, warmth and aesthetics of the home environment. Most parasites live and breed in feces and are transmitted to humans when ingested. Fecal matter enters the house through various modes of transmission, including on the shoes of people, through animals, spillage of unclean water, and from young children with inadequate diapers. Dirt floors provide a vector for parasites to infest people, especially young children, since fecal matter tends to remain on the floor because it is less easy to spot and dirt floors are not easy to clean. Emma Marianela Morales-Espinoza, et al. (2003) find that among deprived households in Mexico, ceteris paribus, children residing in houses with dirt-floors are more likely to be infected with intestinal parasites. Similar evidence is found for other Latin American countries (see, among others, M. I. Gamboa, et al. (1998) for Argentina; Kathryn H. Jacobsen, et al. (2007) for Ecuador; and Adriana S. Lopez, et al. (2003) for Haiti).

Parasitic infestations pose serious threats to young children, as more than 3 million children die from parasitic diseases each year (World Bank (2002)). Among those who survive, parasitic infestations are associated with diarrhea and micronutrient malnutrition, which often leads to iron-deficiency anemia, protein-energy malnutrition, and enlargement of the liver and spleen (see, among others, Roy M. Anderson and Robert M. May (1992) and M. S. Hesham, A. Edariah and M. Norhayati (2004)). Currently, anemia, which leads to slow cognitive development, is a widespread global health problem (see, among others, C. Nokes, et al. (1992) and Ernesto Pollit (1990)).

By providing cement floors to households with dirt floors, Piso Firme interrupts the transmission of parasitic infestations, particularly for young children. For this reason, we expect to find lower incidence of diarrhea, malnutrition and micronutrient deficiency (particularly anemia) and thereby improved cognitive development among children in beneficiary households. Our study of this intervention is similar in spirit to the study by Edward Miguel and Michael Kremer (2004), which evaluated the impact of chemotherapeutic de-worming of school-aged children using a randomized experiment in Kenya and found that such de-worming reduced school absenteeism by one quarter. Our study complements Miguel and Kremer's results as we demonstrate that cement floors can reduce the incidence of those parasites (amoebas) that remain even after de-worming.

\footnotetext{
${ }^{5}$ Laying the cement typically takes 30 minutes per household, and requires 4 hours to dry.
} 
In addition to analyzing the health effects of Piso Firme, we expect that as a result of the improved home environment, family members may enjoy spending time in the home with cement floors more than they did with dirt floors. Therefore, we hypothesize that one would be happier and less depressed living in a cleaner, warmer and more aesthetically pleasing environment.

\section{Identification Strategy}

In order to identify the impacts of replacing dirt floors with cement floors, we need to assess the counterfactual -i.e., to examine what would have happened to the households in the treatment group had they not received treatment. We exploit geographical variability in the implementation of the program to construct a comparison group that estimates this counterfactual. ${ }^{6}$

This study focuses on the State of Coahuila, in Northern Mexico, which began implementing Piso Firme in the year 2000 and provided cement floors to more than 34,000 households by 2005. While Piso Firme began as a state program in Coahuila, it was later adopted by the Federal Government and gradually scaled up to other states over time. One state that did not fully scale up Piso Firme by 2005 was the neighboring State of Durango. This state committed to implement Piso Firme in 2004 as part of the national scale up, and had just started limited rollout in 2005. Durango straddles the south-western corner of Coahuila and shares a major urban area.

In order to ensure that the treatment and control groups are comparable in terms of observable characteristics, we implemented the following sampling procedure. First, we geographically restricted the sample to families residing in the twin cities of Gómez Palacio and Lerdo (control) and Torreón (treatment) that straddle the border of the States of Durango and Coahuila, respectively. Piso Firme program had not yet reached Gómez Palacio and Lerdo by the time of our survey in the spring of 2005, nor had Durango announced if or when these two cities would receive the program. In addition, there are no major barriers between Gómez Palacio/Lerdo and Torreón; instead, neighborhoods spill across the two states' border forming a single urban agglomeration. Although the two cities are split administratively between the two states, they are effectively a single urban area in socio-economic terms. In principle, households residing near the border in these cities are likely to be similar except for the influence of state policies.

Second, we randomly drew the sample of treated households from administrative records of the universe of households that were included in Piso Firme in the city of Torreon in the State of Coahuila between 2001 and 2003. Since data collection was conducted in the spring of 2005, this time frame provides us with a sample of treated household with 2-4 years of exposure to treatment.

Third, using pre-intervention information gathered from the 2000 population census, we identified the census blocks (AGEBs) where our sample of treated households was located and calculated average pre-treatment characteristics at this census level. Similarly, we also identified a sample of census blocks in the cities of Lerdo and Gómez Palacio that were geographically close to the border with Torreón.

\footnotetext{
${ }^{6}$ As a retrospective study where benefits had already been assigned to the universe of eligible population, random assignment of the treatment was not feasible, and so an alternative source of exogenous variation was required to construct valid a counterfactual.
} 
Fourth, using a minimum distance algorithm, we matched samples of treated and potential control census blocks using data on the following pre-treatment characteristics at the census block level: (i) proportion of blocks within each census block with dirt floors; (ii) proportion of households with dirt floors; (iii) number of children between 0 and 5 years of age; and (iv) number of households. Specifically, we calculated the distance measure as the maximum of the absolute value differences between these four variables ( $L$-infinite distance) for each possible pair of treatment and control census blocks. We then selected as control areas those census blocks that were closest to the treated areas in terms of this distance measure. The sample of control households was randomly drawn from the blocks within these specific selected areas, conditional on the presence of dirt floors in 2000.

Finally, we imposed the following eligibility criteria on all (i.e., both treatment and control) surveyed households: (i) households had to own the house where they reside, since homeownership is an eligibility requirement for the Piso Firme program; (ii) the family groups must have resided in that specific dwelling since 2000; (iii) the houses must have had at least one room with a dirt floor in 2000 (since, otherwise, the household could have not received the program benefits); and (iv) households must have at least one child younger than the age of 6 at the time of the interview. This last requirement was based on the fact that the treatment was expected to render its main health benefits to individuals in this age group.

\section{Data}

The data for all of our analyses comes from a cross-sectional household survey of control and treatment groups that we conducted together with the Mexican National Institute of Public Health in the spring of 2005. We supplement these data with information from the 2000 Mexican Census, the vital statistic mortality files and the 1994 through 2000 national household surveys. These supplement data are used solely for the purposes of checking pre-intervention control and treatment group balance in the levels and trends of key characteristics.

The survey's target sample size was 3,000 households, equally split between treatment and control groups. Response rates were very high. In the treatment area, the response rate was 92.6 percent or 1,390 completed surveys, while in the control area the response rate was 92.9 percent or 1,393 completed surveys. Of these 2,783 households, we have complete geographical location information for 2,755 of them (99 percent). This group constitutes the final sample used in this analysis.

We collected detailed information on household demographic structure, socio-economic status, housing infrastructure (including detailed information on the type of floor in each room of the house), health outcomes and cognitive development of children under 6 years of age, as well as happiness and mental-health indicators for their mothers. All variables measured contemporaneous values at the time of the survey, except for the share of rooms that had cement floors in 2000, which is a retrospective measurement. Table 1 provides a description of all the outcomes used in this study and the corresponding sample sizes.

The child health and development outcomes include: (i) maternal-reported cases of diarrhea in children in the four weeks prior to the survey, (ii) stool samples to determine the prevalence of parasites in fecal matter, (iii) height and weight anthropometric statistics to measure stunting and wasting, (iv) blood from a finger prick to assess hemoglobin levels and anemia, and (v) measures of language and communication ability. 
In order to measure the presence of intestinal parasites, we collected two stool samples from every child under 6 years of age. We used standard parasite ova centrifuge concentration techniques on the fixed specimens with direct visualization in order to detect the presence of 19 different types of common parasites, both worms and protozoa (D. M. Melvin and M. M. Brooke (1982)). ${ }^{7,8}$ We then compared the measurement for the two samples and found convergence in over 99 percent of the subjects.

We measured the height and weight of all the children less than 6 years of age using standard international procedures and regularly calibrated portable scales and stadiometers. The measurement instruments were regularly recalibrated (twice weekly) in the field. Repeated measurements were taken of all children in order to monitor quality control. In accordance with World Health Organization guidelines, we converted these measurements into height-for-age and weight-for-height z-scores, which measure the number of standard deviations from age-sex standardized height of a healthy (U.S.) reference population.

In order to measure anemia, we collected blood samples by means of digital capillary punctures (i.e., finger pricks). At the time of collection, we placed one drop (10 $\mu \mathrm{l})$ of blood in a portable photoreflectometer to measure the concentration of hemoglobin in the blood. During the fieldwork, the photometers were calibrated twice weekly, and the measurements of the control tray were recorded at the beginning and end of each day. The hemoglobin results were immediately available in the household and enabled the survey team to inform the family whether the child was at risk of anemia. In addition, we provided children with hemoglobin values of less than $9 \mathrm{~g} / \mathrm{dL}$ with a ferrous sulfate treatment. For the purpose of our analysis, according to international standards, we define a child to be anemic if his or her hemoglobin level is less than $11 \mathrm{~g} / \mathrm{dL}$, adjusted for the altitude of his or her area of residence using standard adjustments (Centers for Disease Control and Prevention (1998)).

We measured child cognitive development using two different indicators. First, for children aged from 12 to 30 months, we applied the Spanish version of the MacArthur Communicative Development Inventory (CDI, Cognitive Development Laboratory at San Diego State University). This instrument appraises language and communication skills in infants and young children through parental reporting. In the field, we used the short infant form ("Versión Breve del Inventario del Desarrollo de Habilidades Comunicativas-Inventario I"), which includes a 105-word vocabulary checklist with separate columns to report comprehension and verbalization of each word. This short form is recommended when parental literacy is low, as is the case in our study.

Second, for children aged 36 to 71 months, we applied the Spanish version of the Picture Peabody Vocabulary Test (PPVT) (“Test de Vocabulario en Imágenes Peabody (TVIP)”) (Lloyd M. Dunn, 1965). Based on the PPVT, the TVIP contains 125 translated items to assess the vocabulary of Spanish-speaking and bilingual children. Items have been carefully selected based on a rigorous item analysis for their universality and appropriateness for Spanish-speaking

\footnotetext{
${ }^{7}$ The parasite count does not include Blastocystis Hominis (BH). The reason for excluding this parasite is that cement floors do not intercept the transmission of this parasite as it is transmitted through other mechanisms (see Kevin S. W. Tan, Mulkit Singh and Eu Hian Yap (2002)). Indeed, there are no statistically significant differences between the prevalence of $\mathrm{BH}$ in the treatment and control groups. Under the assumption that the Piso Firme program is not effective in reducing the presence of this intestinal protozoan parasite, this finding also provides suggestive evidence of the comparability of the treatment and control groups.

${ }^{8}$ We did not find worms in our sample, only protozoa (amoebas). This is due to the fact that residents of both the treatment and control areas are being regularly de-wormed through the distribution of albendazole to the households in these areas.
} 
communities. The TVIP is frequently used to evaluate the language development of Spanishspeaking preschool children, as well as older students (F. Muñoz, et al. (1989) and Vivian M. Umbel, et al. 1992). We report the results in terms of the percentile distribution of Latin American outcomes.

Finally, we measured happiness of the mother using a rich set of indicators. First, we asked about their satisfaction with floor quality, overall housing quality and quality of life. The possible answers were: (i) very satisfied, (ii) satisfied, (iii) fair, and (iv) unsatisfied. In the empirical analysis reported in this paper, we convert these responses into a binary variable that equals one if the answer is in categories (i) or (ii) and zero otherwise.

Second, we collected measures of depression and perceived stress for mothers of children younger than six years of age. In order to measure stress, we implemented the Perceived Stress Scale (PSS) developed by Sheldon Cohen, Tom Kamarck and Robin Mermelstein (1983). We used a ten-item version of the PSS designed to capture the degree to which mothers found their lives to be unpredictable, uncontrollable and overloaded during the month prior to the interview. Answers were given on a scale from 0 to 5 . Four of the questions were positively worded while the other six were negatively worded. We obtained the PSS score by reversing the scores for the answers to the positively worded items and then summing up the scores across the answers of the ten items. Therefore, a higher score signifies a higher level of perceived stress on a scale of 0 to 40.

To measure depression, we implemented the Center for Epidemiologic Studies Depression Scale (CES-D Scale) designed by Linore S. Radloff (1977). This instrument measures the current level of depressive symptomatology, including depressed mood, feelings of helplessness and hopelessness, psychomotor retardation, loss of appetite and sleep disturbance. This instrument contains twenty items. Answers were divided into five categories that were then mapped on a scale ranging from 0 to 4 . Four of the items were positively worded while the others were negatively worded. We obtained the CES-D score by reversing the scores of the answers to the positively worded items and then summing up the scores across the answers for the twenty items. Therefore, a higher score denotes a higher level of perceived depression, measured on a scale of 0 to 60 .

Finally, note that both the PPS and CES-D scales fit the data well. We rely on Cronbach's alpha to measure how well the set of items used measures a single one-dimensional latent index (Lee J. Cronbach (1951)). The alpha for PPS is 0.79 and for CES-D is 0.86. Most studies consider a score of 0.8 or higher to be appropriate.

\section{Treatment and Control Group Balance}

In order to substantiate the causal interpretation of our estimates, we first determine that the control and treatment groups are well balanced in terms of a large set of observable characteristics. We also show that treatment and control areas were also displaying very similar secular socio-economic environments before and after the program Piso Firme was adopted by the State of Coahuila.

\section{A. Treatment and Control Group Balance in Levels}

We begin by examining the comparability of treatment and control groups in terms of a large set of observable pre-treatment variables. If the two groups turn out to be different in terms of 
these observable variables, then it is likely that they would also have displayed differences in terms of child health and maternal happiness in the absence of treatment, thereby invalidating our identification strategy. We first compare the pre-intervention balance in terms of characteristics measured in the 2000 census, and then consider a larger set of variables collected in our 2005 survey.

In principle, we would like to assess the pre-intervention balance using our sample of households in the 2005 survey. While we do not observe these households directly in 2000 prior to the intervention, we do have information about households from the census blocks used to draw our sample in 2005. Hence, we are able to compare the pre-intervention balance in terms of characteristics measured in the 2000 census for the census blocks used in our 2005 survey. In addition, we also assess directly control and treatment group balance using plausibly exogenous variables collected in our 2005 survey.

Table 2 compares the means for 22 variables at the block level gathered from the 2000 census for treatment and control areas, prior to the implementation of the Piso Firme program in the State of Coahuila. These variables measure household demographic structure, housing characteristics, assets, poverty and education of household members. For each of these variables, we present the means and standard errors for both treatment and control groups, as well as their mean differences and respective standard errors. All standard errors in this paper are clustered at the census-block level.

The first four variables in Table 2 were used to match the sampling of treated and control census blocks, and they are therefore balanced in our sample. One of these variables is the proportion of households that report having dirt floors in 2000, which is particularly important since reducing the presence of dirt floors is the direct objective of the intervention. In addition, there are no significant differences in the other eighteen pre-treatment variables presented in Table 2. Thus, we conclude that the treatment and control areas from which we drew our samples were well balanced prior to the intervention and this increases our confidence that the treatment and control groups were comparable prior to the implementation of the program. ${ }^{9}$

Next we investigate whether the actual treated and control households in our 2005 sample are well balanced in terms of variables that can reasonably be considered exogenous to the intervention studied. This provides further evidence in favor of our identification strategy. Ideally we would like to compare treatment and control households in our survey prior to the intervention. However, this information is not available and we are forced to relay on the variables in our 2005 survey under the working assumption that these variables were not affected by Piso Firme. In particular, we focus on variables that are either retrospective or reasonable arguably exogenous to the intervention.

Table 3 compares the balance between treatment and control households with respect to 27 variables that were collected in our 2005 survey. ${ }^{10}$ These variables are grouped into six different categories: household demographics, children's characteristics, housing characteristics, hygienic environment, economic variables and benefits from public social programs. In our view, except for the economic characteristics, ${ }^{11}$ the variables included in this table are likely to be unrelated to the treatment studied, and as such, are reasonably good instruments for testing balance between

\footnotetext{
${ }^{9}$ Computing these mean differences at the household level by assigning each household the value of the variables corresponding to its census block does not change the results. All mean differences remain insignificant.

${ }^{10}$ All variables in this table are contemporaneous with the time of the survey with the only exception of Share of rooms with cement floors in 2000, which is a self-reported retrospective variable that refers to the year 2000.

${ }^{11}$ We discuss the reasons for the potential endogeneity of the economic variables in Section VI.
} 
treatment and control groups. As in Table 2, we also present the means and standard errors of these variables for both treatment and control groups, as well as their mean differences and respective standard errors.

Turning to the results reported in Table 3, notably almost all of the variables presented in this table are statistically balanced. No variables present statistically significant mean differences at the 5 percent level and only 2 of these 27 variables present significant differences at the 10 percent level, something that is likely to occur even when the true mean values of these variables are the same between both groups.

We start by noting that there are no differences in the household's retrospective recall of the share of rooms with cement floors in 2000, prior to program intervention. This is important because it implies that treatment and control groups are comparable in terms of the key measure of Piso Firme's objective, replacing dirt floors, at baseline. We also note that households are well balanced in terms of other current housing characteristics, such as number of rooms, water and electricity connections.

Households are also well balanced in terms of current household demographics and the characteristics of young children, number of household members and characteristics of the head and spouse of the head. The characteristics of young children are on average the same in terms of own age, mother and father age and education, as well as the probability that the mother is present. Of note, however, is that the proportion of male children in the control group is 0.517 compared to 0.492 in the treatment group and that this difference is statistically significant at the 10 percent level. Additionally, the proportion of children whose father is present in the household is 0.763 in the control versus 0.797 in the treatment and this difference is also statistically significant at the 10 percent level. We control for these characteristics in the analysis to test the robustness of the estimates to these deviations.

The current health and hygienic environments of the control and treatment households are also well balanced. Households in both groups have the same share of municipal water connections on their land plot and inside their houses, as well a similar access to electricity services. They also have similar hygiene habits as measured by the presence of animals in and around the house, hand-washing behavior, and garbage disposal behavior.

Furthermore, the two economic variables included in this table -total household income per capita and total assets per capita- are statistically indistinguishable between treatment and control groups. This result shows that the current socio-economic status is similar between both groups and likely unaffected by Piso Firme. ${ }^{12}$

Finally, the same proportion of treated and control households benefit from public programs likely to affect nutritional outcomes. We consider two types of programs: nutrition specific programs and any program that provides cash transfers. Both treatment and control households receive similar amounts of monetary transfers per capita. Note, also, that on average, these households receive between 60 and 80 Mexican pesos per household per month in transfers from public social programs, which represents a very small share (approximately 1 percent) of the households' average income. Overall, we conclude that these findings imply that treated and control groups are well balanced and provide credibility to our identification strategy.

\section{B. Treatment and Control Group Balance in Secular Trends}

\footnotetext{
${ }^{12}$ Households in our sample are not extremely poor. On average, their monthly income is approximately equal to the value of the poverty line.
} 
We showed in the previous section that the treatment and control groups are balanced in terms of a large set of observable variables. Despite the fact that these households reside in a fundamentally homogenous environment, it is still possible that there might have been different secular trends between the states of Durango and Coahuila, and that these differences could have affected the outcomes of interest considered in this paper. In order to address this concern, we now turn to investigate the secular behavior of a large set of variables from publically available datasets.

First, in Figure 1, we present the annual time series of both the total mortality rate and the child mortality rate for the municipality of Torreón in the State of Coahuila (treatment) and the municipalities of Gómez Palacio and Lerdo in the State of Durango (control) for the period 1994-2001. ${ }^{13}$ In both cases these variables present very similar secular trends during the period previous to the adoption of Piso Firme by the State of Coahuila. Not only do the treatment and control series have the same trends, but also they have the same levels in the case of total mortality rates. Note that in the case of child mortality the treatment area exhibits somewhat higher levels suggesting that, if anything, the control group may have been relatively healthier before the adoption of Piso Firme.

Second, in Figure 2, we present bi-annual time series for the period 1994-2000 for the following aggregate variables: a) Number of children 0-5 years old per household; b) number of rooms per household; c) real household income per capita; d) real total consumption per capita; and e) real expenditures in health services per capita. These series were constructed using state level data from the Income and Expenditure National Household Survey (Encuesta Nacional de Ingresos y Gastos de los Hogares (ENIGH)). We report the mean level for each variable and its corresponding 95-percent confidence interval. As can be seen from this figure, all variables present both the same levels and trends for the states of Coahuila and Durango. This suggests that both before and after Piso Firme was implemented both states exhibited very similar health and socio-economic environments. ${ }^{14}$

\section{Program Impacts}

We subsequently study the effect of Piso Firme on several outcome variables of interest including child health and maternal happiness indicators. We begin by demonstrating that offering the benefits provided by Piso Firme had an impact in terms of the presence of cement floors in the corresponding households. This is a necessary condition for Piso Firme to have an impact on child health and maternal happiness through the pathways discussed in Section I. We first present evidence on the differences in state level trends in cement floors and then estimate the impact of Piso Firme on the installation of cement floors using our sample.

We report the results of an intention-to-treat analysis for the Piso Firme program on the outcomes of interest. We estimate this parameter by regressing the dependent variable on a

\footnotetext{
${ }^{13}$ The mortality data are available from vital statistics records in the Mexican Department of Health. Mortality rates are computed as the number of annual deaths over the relevant population times 100.

${ }^{14}$ Using the data from ENIGH, we actually constructed a much larger and rich set of variables for the analysis. In all cases, these variables displayed the same levels and trends for both states. The list of variables includes: (i) demographic variables (average education of the head of the household, average education of spouse, children's gender composition); (ii) access to utilities and services variables (average access to public water, average access to the electricity system, and average access to the garbage collection service); and (iii) socio-economic variables (average proportion of working household members, average hours worked per capita, and income and expenditure disaggregated by different sources). These results are available upon request.
} 
variable indicating whether or not the household was offered this benefit and a large set of control variables. The intention-to-treat dummy variable is equivalent to a dummy variable that indicates whether or not the household resides in the treatment area, since all the households in our sample residing in treatment areas were offered this benefit, whereas it was not offered to any of the households residing in the control areas.

For each dependent variable, we estimate three different linear regression specifications. ${ }^{15}$ Model 1 estimates the treatment effect on the response variables studied without including any control variables. We regress each outcome variable on a dummy variable that takes on the value one if the household was offered Piso Firme and zero otherwise. Model 2 adds demographic and health control variables. The demographic controls include household size, number of rooms in the house, years of education completed by the head of household, years of education completed by the spouse, age of the head of household, age of the spouse, and demographic group-specific variables. ${ }^{16}$ The health environment and hygiene habits controls include a dummy variable indicating whether the household has dogs, cats, chickens or pigs, a dummy variable indicating whether these animals enter the house, a dummy variable for water connections outside the house, a dummy variable for water connections inside the house, a dummy variable indicating whether the household is connected to the electricity system, the number of times that the survey respondent washed his or her hands the day before the interview, and a dummy variable indicating whether the household uses a garbage collection service. ${ }^{17}$ Finally, Model 3 adds controls for the benefits from other social programs including total monetary transfers per capita from all social programs received by the household, a dummy variable indicating whether the household benefited from a government milk supplement program, a dummy variable indicating whether the household benefited from any other government food program, and a dummy indicating whether the household was enrolled in Seguro Popular, a government health insurance program.

In the first column of each table, we report the mean value of the outcome variable for the control group to be able to gauge the size of the estimated coefficient. In all cases, we report the point estimate, its clustered standard error, and the average program effect as a percentage of the mean of the dependent variable for the untreated households. ${ }^{18}$ All models are estimated clustering the errors at the census block level. The number of clusters in our sample is 136, a number large enough for using asymptotic inference (see Colin Cameron, Jonah B. Gelbach and Douglas L. Miller (2008)). All the findings in this section remain valid if robust standard errors are computed instead of clustered standard errors.

\section{A. State Level Cement Floors Secular Trends}

\footnotetext{
${ }^{15}$ When the outcome variable was dichotomous, we also estimated the average treatment effects by computing the marginal effects of the intention-to-treat dummy variable on the outcomes after estimating probit models. The estimated effects are similar, and all of them are statistically significant at conventional levels. These results are available upon request.

${ }^{16}$ In particular, for regressions at the household level (Tables 4, 6 and 7) we included 8 variables measuring the sex/age groups proportion of household members, while for regressions at the individual level (Tables 5 and Table 6) we included quarterly sex/age dummies for each child.

${ }^{17}$ All the results in this paper are unaltered if we also add total income per capita and total assets value per capita as control variables in the models. These results are available upon request.

${ }^{18}$ To preserve parsimoniousness, we do not report the estimated coefficients of the control variables, but those are available upon request.
} 
Before turning to the regression analysis of the effect of Piso Firme on the adoption of cement floors, we examine the evolution of the prevalence of cement floors at the state level. Using data from ENIGH for the period 1994-2006, we show in Figure 3 that the proportion of households which floors are predominantly made of cement were similar in both states in terms of levels and secular trends before Piso Firme was implemented in Coahuila. As expected, once the program is in place both series start to diverge with the share of households which floors are predominantly made of cement being now very close to one in the treatment area.

\section{B. Estimated Program Impact on Cement Floors}

Now we turn to analyze the impact of offering Piso Firme's benefits on the presence of cement floors in treatment houses in our sample. This tests the effect of the program in terms of its primary objective (i.e., the coverage of cement floors in the household), as families not offered the program might have replaced their dirt floors on their own over time. ${ }^{19}$ We examine a number of alternative outcome indicators: (i) share of rooms that have cement floors; (ii) a dummy variable indicating whether the kitchen has cement floor; (iii) a dummy variable indicating whether the dining room has cement floor; (iv) a dummy variable indicating whether the bathroom has cement floor; and (v) a dummy variable indicating whether all household members sleep in rooms with cement floors.

The results are displayed in Table 4. Control households report that 73 percent of their rooms had cement floors in 2005, up from 33 percent in 2000. This implies that in control areas there was a 40-percentage point increase in cement floors without Piso Firme. This is not surprising as this was a period of strong economic growth in Mexico and an expansion of Mexico's generous cash transfer program, Oportunidades, to urban areas. Sergio A. Bautista and Paul J. Gertler (2008) show that Oportunidades beneficiaries invested some of the cash transfers in housing improvements including replacing dirt floors with cement floors.

Despite this large secular increase in cement floors, we find that Piso Firme had large positive effects on the installation of hard floors across all the indicators studied. Piso Firme brought about an average increment in cement flooring of about 28 percent in the share of rooms with cement floors. We find stronger effects in the kitchen (38 percent) and sleeping areas (36 percent) of these households. ${ }^{20}$ In sum, Piso Firme succeeded in prompting households to install cement floors for almost all their household floor space. These findings are extremely robust to all specifications presented in Table 4, confirming that the control and treatment groups are indeed well balanced.

\section{Estimated Program Impact on Child Health}

Table 5 presents the intention-to-treat analysis of the impact of Piso Firme on the health outcomes of children less than six years of age. The outcome indicators include parasitic infestations, diarrhea, anemia, height, weight and cognitive development. We find that the

\footnotetext{
${ }^{19}$ This might occur because of the existence of an aggregate secular upward trend, but also because of idiosyncratic motives. In particular, it seems to be the case that poor households replace their dirt floors by cement floors last in the construction of their houses. Investment in walls, ceilings, sanitation facilities and kitchen generally precede investment in cement floors in self-constructed houses in poor areas.

${ }^{20}$ Indeed, there is a convergence in the percentage of total floor space represented by cement floors in untreated households, since the households with a larger proportion of dirt floors in 2000 are among those that increased the share of cement flooring the most during the period considered.
} 
program is significantly associated with the presence of fewer parasites, a lower incidence of diarrhea and anemia, and better cognitive development of young children. Moreover, these results are extremely robust to the inclusion of all sets of covariates.

Specifically, offering the program is associated with a 19.6 percent reduction in the presence of parasites. The program is also associated with a 1.8 percentage-point decrease in episodes of diarrhea, which represents a 12.8 percent reduction in the prevalence of diarrhea with respect to the control group. Piso Firme is also associated with an 8.5 percentage-point reduction in the incidence of anemia, which translates into a 20.1 percent decline in the prevalence of anemia with respect to the control group. We do not find any significant difference, however, in the usual height and weight anthropometric indicators.

Finally, the program is also associated with notable improvements in child cognitive development. We find that treated children have a 30.2 percent higher score on the McArthur test and show an improvement in the PPVT test equivalent to an increase with respect to the control group of about 9 percent.

These child health results are consistent with the hypothesis that replacing dirt floors with cement floors interrupts the transmission of parasitic infestations and should therefore reduce the incidence of both diarrhea and anemia. The reduction in anemia is expected to have positive effects on cognitive development. ${ }^{21}$

\section{Estimated Program Impact on Maternal Happiness}

Table 6 presents the results of the intent to treat analysis for maternal satisfaction and mental health. Again, the program effects are positive, significant, and robust to all specifications. The degree of satisfaction with the quality of the floors is 22 percentage points higher in the treatment group, which is 42.8 percent greater than the control mean. ${ }^{22}$ Similarly, the level of satisfaction in the treatment group with the overall quality of the house is 15.1 percent higher than the control group's mean, while satisfaction with quality of life is 18.7 percent higher than the control mean. ${ }^{23}$ The last two rows of the table show the effects of the program on maternal mental health. We find that the depression and perceived stress scales are significantly lower in the treatment group with an estimated effect that represents a 12.5 percent and 10.6 percent difference from the control mean, respectively.

\section{Robustness Checks}

\footnotetext{
${ }^{21}$ Alternatively, one can try to identify the effect of actually replacing dirt floors with cement floors, ceteris paribus, by regressing any of the dependent variables of interest on the share of cement floors and instrumenting this potentially endogenous variable by the exogenous intention-to-treat dummy variable (i.e., a dummy variable that indicates whether or not the household was offered the program treatment). Doing this procedure, we find that a complete substitution of dirt floors by cement floors in a house would lead to a 78 percent reduction in parasitic infestations, a 49 percent reduction in diarrhea, an 81 percent reduction in anemia and a 36 to 96 improvement in cognitive development among young children.

${ }^{22}$ Rafael Di Tella and Robert MacCulloch (2006) and Daniel Kahneman and Alan B. Krueger (2006) have recently advocated the use of happiness indicators in assessing economic outcomes.

${ }^{23}$ To check the robustness of these results to the way we classify the more ambiguous answer "fair", we also estimated the same set of regressions for an alternative measure of satisfaction, where the response "fair" was assigned a 1 instead of a 0 . All the results remain unchanged when this alternative classification is used. These additional results are available upon request.
} 
In this section we address three important concerns related to our empirical work. First, we examine the possibility that there were other public programs that could explain our results and carry on a series of falsification tests that provide further support for our identification strategy. Second, we examine whether the pathway by which Piso Firme affected child health is interruption of the transmission of parasitic infections or economic benefit. Finally, we provide evidence that the specification of the clustering structure used in our regression models is consistent with the hypothesis of no spatial serial correlation between clusters.

\section{A. Potential Bias from Other State and Local Programs}

We hypothesized that replacing dirt floors interrupted the transmission of parasitic infestations and that this led to the improvements observed in the other child health outcome indicators. However, there could have been other state-specific changes that coincided with the implementation of Piso Firme in Coahuila which may have been at least partially responsible for the outcomes observed. For example, improvements could have been made in the health-care system in the State of Coahuila, but not in Durango.

We have already tried to rule out the influence of other state specific programs in a number of ways. First, we have shown that the sample is balanced across a large number of demographic, health and socio-economic characteristics prior to the program (Table 2). Second, we have shown that trends in health and socio-economic variables prior to the introduction of Piso Firme were the same for both control and treatment groups (Figures 1 and 2). These facts are consistent with the hypothesis that there were no programmatic or policy differences that affected health and socio-economic outcomes prior to the introduction of Piso Firme. We also showed that all of the socio-economic characteristics of the household were balanced across treatment and control groups in 2005 (Table 3) and that there were no differences in the time trends over this period as well (Figure 2). This suggests that there were no differences in programs of policies that affected socio-economic outcomes over the period. Fourth, we explicitly controlled for participation in a number of social programs in the analysis including nutrition programs, cash transfer programs and Seguro Popular, a public health insurance program for the poor. Finally, we verified that over the period under study there were no other state or local programs targeting health, nutrition or parasites based on interviews with national and local officials.

In this section, we present further evidence that rules out the possibility that the results presented in the previous section are the consequence of confounding causes. We first consider other diseases that could presumably not have been affected by the replacement of dirt floors with cement floors: respiratory diseases and skin lesions. We then explore if there are differences among all other diseases between treated and control households using the same methods as in the impact analysis section above. This is a falsification test to investigate whether other interventions that were correlated with the implementation of Piso Firme could account for the above results. As can be seen from Table 7, the treatment dummy variable is not significantly associated with any of these illness measures.

\section{B. Pathways}

We hypothesized that the pathway by which Piso Firme affected child health is through interrupting the transmission of parasitic infestations. However, an alternative pathway could have been through the program's effect on economic resources. Piso Firme provides a benefit 
amounting to approximately 150 US dollars, which is equivalent to about one-half months' income. If a beneficiary household had already decided to save and invest in cement floors, it could have used the resources freed up by this in-kind transfer to increase consumption or to make other kinds of investments, such as additional housing investments that could affect health outcomes or in microenterprises that might increase household income.

Table 7 presents evidence that rules out this alternative economic resource channel as an explanation of the effects of the program on child health. Using the same methods as in the program impact section, we find that the program is not associated with the value of houses. The variables reported in these columns are self-reported: household members were asked how much they thought they could rent and sell their houses for. These results show that treatment households did not consider their houses to be more valuable than control households did. Also, different measures of household income and total consumption are not associated with the treatment dummy, ${ }^{24}$ which shows that there are no systematic differences in income or consumption levels between treatment and control households.

In addition, Table 7 shows that, except for their floors, treated households did not improve their houses more than control households did. The variables considered are the construction and expansion of sanitation facilities, the restoration of sanitation facilities, the construction and expansion of rooms not containing sanitation facilities, the construction of ceilings, and the restoration of the electricity system and the house's walls. All estimated coefficients are small and none of them are statistically significant. We also study whether offering Piso Firme affected the likelihood of making any improvement in the treatment houses. In particular, we constructed an indicator variable that takes a value equal to one if the household reports having any improvement since 2000 (excluding the installation of cement floors), and we find no effects here either. In sum, these results suggest that the program did not have the effect of encouraging households to improve their houses further.

\section{Specification Test for Clustered Standard Errors}

Even though the original sampling procedure designed in our survey naturally motivated our clustering structure, this structure might be inappropriate if the error terms of the models were correlated across clusters. Using standard methods from the literature on spatial autocorrelation, we address this concern by testing the null hypothesis of no-spatial serial correlation for each regression estimated in this paper.

In particular, we implement this test by computing a between-cluster Moran's I test statistic based on the distance between clusters following the procedure discussed in Harry H. Kelejian and Ingmar R. Prucha (2001). ${ }^{25}$ In order to test the null hypothesis of no-spatial serial correlation while allowing for within cluster correlation of the residuals, we implemented the test as follows. First, we estimated the residuals for the individual level regressions. Second, we averaged these residuals at the cluster level, leading to 136 (average) residual estimates per regression. Finally, using the between-cluster estimated average residuals obtained in the second step we carried on

\footnotetext{
${ }^{24}$ This result is consistent with Table 3, where in addition the value of household assets per capita and total income per capita do not significantly differ between treatment and control households. Moreover, similar results are obtained when analyzing (i) proportion of household members who work, (ii) whether the household operates a microenterprise, and (iii) hours worked by household members per capita. These results, not presented in the paper, are available upon request.

${ }^{25}$ See equations 2.4 and 4.1 in Kelejian and Prucha (2001) for the test statistic and asymptotic distribution, respectively.
} 
the Moran's I test as discussed in Kelejian and Prucha (2001) using the Euclidean distance among clusters as weights. In all cases we fail to reject the null hypothesis of zero spatial between-cluster autocorrelation, suggesting that our choice of clustering structure was appropriate. To conserve space, we do not report the test statistics here, but they are available upon request.

\section{Discussion}

The Piso Firme housing program in Mexico grants cement floors to poor households with dirt floors, at an average one-time cost of 150 US dollars per household. In this paper, we show that Piso Firme improves child health and cognitive development, mainly by reducing the incidence of intestinal parasites that are not treatable with albendazole or other common deworming drugs employed in developing countries. We also show that Piso Firme improves adult welfare as measured by mental health and satisfaction with housing.

Our results have a number of important policy implications. First, housing improvement appears to be an important component of anti-poverty interventions, and our results show that major improvements in child health and cognitive development can be achieved by this particular kind of interventions.

Second, replacing dirt floors with cement floors appears to be, in this case, a cost-effective policy for improving child cognitive development. The cost of replacing dirt floors is a one-time $\$ 150$ expenditure and yields an increase of about 9 percent in the Picture Peabody Language Development Test score. This compares favorably to the effect of Mexico's OPORTUNIDADES conditional cash transfer program (formerly called PROGRESA) which yields only a 12 percent increase in the Picture Peabody Language Development Test score after two years on the program at a cost of between $\$ 210$ and $\$ 750$, and to Ecuador's cash transfer program at a cost of \$210 for two years of benefits (Fernald, Gertler and Neufeld (2008) and Christina Paxson and Norbert Schady (2008)). The effect sizes of Piso Firme are also comparable to those from early childhood development and nutrition programs assessed in a recent review by Engle, et. al. (2007).

Third, de-worming drugs such as Albendazole are only partial substitutes for cement floors. In our sample, Albendazole was regularly administered to almost all children, as Mexico has had a large and active deworming program with nearly universal coverage at the national level for many years. The program provides Albendazole to all children in the country several times a year through health clinics, door to door campaigns, and in schools. The chemotherapy appears to have worked, as we found almost no infestations of parasitic worms in the analysis of the fecal samples we collected. However, we found a large prevalence of parasitic protozoa infestations that are not sensitive to Albendazole, and an associated large incidence of diarrhea and anemia. In fact, parasitic protozoa infestations accounted for 98 percent of the parasites found in the fecal samples in our survey. At the moment, there are no cost-effective pharmacological interventions to prevent or treat parasitic protozoa infestations on a mass scale and we know of no such programs designed to reduce parasitic protozoa infestations in the world. Interviews with the Government of Mexico and the State Governments confirmed that they have no programs to treat these types of parasites. Chemotherapies for protozoa are much more expensive and they need to be administered more frequently.

While the estimated effect sizes for both child health and development and maternal happiness are large, one should be cautious in using these estimates to forecast what would 
happen in other settings. Both treatment and control groups in our study live in urban areas where a large percentage of the population already had cement floors; in addition, both groups have access to safe municipal water supplies, and their children are well nourished. Our results would probably not apply to rural areas, where the share of total floor space covered by cement floors in a given house is less likely to have an effect on how often children come into contact with parasites. Similarly, replacing dirt floors with cement floors may be less effective when households do not have access to safe water supplies, since this would remain a major pathway for parasitic infestations, or when children are undernourished and are consequently more susceptible to infestation. In conclusion, replacing dirt floors by cement floors is likely to improve the health of children in low-income urban households where children have been dewormed and families have access to safe water supply. 


\section{REFERENCES}

Anderson, Roy M., and Robert M. May. 1992. Infectious Diseases of Humans: Dynamics and Control. Oxford, UK: Oxford University Press.

Bautista, Sergio A., and Paul J. Gertler. 2008. "Investing Cash Transfers in Housing: Evidence from Mexico's Conditional Cash Transfer Program.” Working paper, University of California, Berkeley.

Becker, Gary S. 1964. Human Capital: A Theoretical and Empirical Analysis with Special Reference to Education. New York, NY: Columbia University Press.

Behrman, Jere R. 1996. "The Impact of Health and Nutrition on Education." World Bank Research Observer 11(1): 23-37.

Bransford, John D. 1979. Human Cognition: Learning, Understanding, and Remembering. Belmont, CA: Wadsworth Publishing Co.

Cameron, Colin, Jonah B. Gelbach, and Douglas L. Miller. 2008. "Bootstrap-Based Improvements for Inference with Clustered Errors." Review of Economics and Statistics, 90(3): forthcoming.

Carneiro, Pedro, and James J. Heckman. 2003. "Human Capital Policy.” In Inequality in America: What Role for Human Capital Policies?, eds. James J. Heckman and Alan Krueger. Boston, MA: MIT Press.

Cebu Study Team. 1991. "Underlying and Proximate Determinants of Child Health: The Cebu Longitudinal Health and Nutrition Study.” American Journal of Epidemiology 133(2): 185-201.

Centers for Disease Control and Prevention. 1998. "Recommendations to Prevent and Control Iron Deficiency in the United States.” MMWR 47 (RR-3): 1-36.

Cohen, Sheldon, Tom Kamarck, and Robin Mermelstein. 1983. "A Global Measure of Perceived Stress.” Journal of Health and Social Behavior 24(4): 385-96.

Cronbach, Lee J. 1951. "Coefficient alpha and the internal structure of tests." Psychometrika 16(3): 297-334.

Chay, Kenneth Y., and Michael Greenstone. 2005. “Does Air Quality Matter? Evidence from the Housing Market.” Journal of Political Economy 113(2): 376-424.

Crane, Randall, Amrita Daniere, and Stacy Harwood. 1997. "The Contribution of Environmental Amenities to Low-Income Housing: A Comparative Study of Bangkok and Jakarta.” Urban Studies 34(9): 1495-1512.

Di Tella, Rafael, and Robert MacCulloch. 2006. "Some Uses of Happiness Data in Economics.” Journal of Economic Perspectives 20(1): 25-46.

Dunn, Lloyd M. 1965. Peabody Picture Vocabulary Test. Circle Pines, MN: American Guidance Service, Inc.

Engle, Patrice L., Maureen M. Black, Jere R. Behrman, Meena Cabral de Mello, Paul J. Gertler, Lydia Kapiriri, Reynaldo Martorell, and Mary Eming Young. 2007. "Strategies to Avoid the Loss of Developmental Potential among 200 Million Children in the Developing World.” Lancet 369: 229-240.

Esrey, S. A., J. B. Potash, L. Roberts, and C. Shiff. 1991. "Effects of Improved Water Supply and Sanitation on Ascariasis, Diarrhea, Dracunculiasis, Hookworm Infection, Schistosomiasis and Trachoma.” Bulletin of the World Health Organization 69(5): 60921. 
Fernald, Lia C. H., Paul J. Gertler, and Lynnette M. Neufeld. 2008. "Role of Cash in Conditional Cash Transfer Programmes for Child Health, Growth, and Development: An Analysis of Mexico's Oportunidades?” Lancet 371: 828-837.

Galiani, Sebastian, Paul J. Gertler, and Ernesto Schargrodsky. 2005. "Water for Life: The Impact of the Privatization of Water Supply on Child Mortality.” Journal of Political Economy 113(1): 83-120.

Gamboa, M. I., J. A. Basualdo, L. Kozubsky, E. Costas, E. Cueto Rua, and H. B. Lahitte. 1998. "Prevalence of intestinal parasitosis within three population groups in La Plata, Argentina.” European Journal of Epidemiology 14(1):55-61.

Gertler, Paul J. 2004. "Do Conditional Cash Transfers Improve Child Health? Evidence from PROGRESA's Controlled Randomized Experiment.” American Economic Review 94(2): 336-341.

Heckman, James J., and Dimitriy V. Masterov. 2007. "The Productivity Argument for Investing in Young Children.” Review of Agricultural Economics 29(3): 446-93.

Hesham, M. S., A. Edariah, and M. Norhayati. 2004. "Intestinal Parasitic Infections and Micronutrients Deficiency: A Review.” Medical Journal of Malaysia 59(2): 284-93.

Jacobsen, Kathryn H., Priscila S. Ribeiro, Bradley K. Quist, and Bruce V. Rydbeck. 2007. "Prevalence of Intestinal Parasites in Young Quichua Children in the Highlands of Rural Ecuador.” Journal of Health, Population and Nutrition 25(4): 399-405.

Jiménez, Emmanuel. 1983. "The Magnitude and Determinants of Home Improvement in SelfHelp Housing: Manila’s Tondo Project.” Land Economics 59(1): 70-83.

Kahneman, Daniel, and Alan B. Krueger. 2006. "Developments in the Measurement of Subjective Well-Being.” Journal of Economic Perspectives 20(1): 3-24.

Katz, Lawrence F., Jeffrey R. Kling, and Jeffrey B. Liebman. 2001. "Moving to Opportunity in Boston: Early Results of a Randomized Mobility Experiment.” Quarterly Journal of Economics 116(2): 607-54.

Kaufmann, Daniel, and John M. Quigley. 1987. "The Consumption Benefits of Investment in Infrastructure: The Evaluation of Sites-and-Services Programs in Underdeveloped Countries.” Journal of Development Economics 25(2): 263-84.

Kelejian, Harry H., and Ingmar R. Prucha. 2001. "On the Asymptotic Distribution of the Moran I Test Statistic with Applications.” Journal of Econometrics 140: 219-57.

Lopez, Adriana S., Jean M. Bendik, Jean Y. Alliance, Jacquelin M. Roberts, Alexandre J. da Silva, Iaci N. S. Moura, Michael J. Arrowood, Mark L. Eberhard, and Barbara L. Herwaldt. 2003. "Epidemiology of Cyclospora Cayetanensis and other Intenstinal Parasites in a Community in Haiti.” Journal of Clinical Microbiology 41(5): 2047-54.

Miguel, Edward, and Michael Kremer. 2004. "Worms: Identifying Impacts on Education and Health in the Presence of Treatment Externalities.” Econometrica 72(1): 159-217.

Melvin, D. M. and M. M. Brooke. 1982. Laboratory Procedures for the Diagnosis of Intestinal Parasites. Atlanta, GA: U.S. Department of Health and Human Services, Centers for Disease Control, Laboratory Improvement Program Office.

Morales-Espinoza, Emma Marianela, Héctor Javier Sánchez-Pérez, María del Mar GarcíaGil, Guadalupe Vargas-Morales, José Domingo Méndez-Sánchez, Margarita Pérez-Ramírez. 2003. "Intestinal parasites in children, in highly deprived areas in the border region of Chiapas, Mexico.” Salud Pública de México 45(5): 379-88. 
Muñoz, F., C. Quilodrán, P. Velásquez, C. Niedmann, A. Baeza, G. Silva, and M. Osorio. 1989. "Acquirement of the Spanish Vocabulary among Rural and Urban Students of the 9th Region.” Revista Chilena de Pediatria 60(6): 354-8.

Nokes, C., S. Grantham-McGregor, A. Sawyer, E. Cooper, and D. Bundy. 1992. "Parasitic Helminth Infection and Cognitive Function in Schoolchildren.” Proceedings of the Royal Society of London, Series B, Biological Sciences 247: 77-81.

Olsen, Edgar O. 2003. "Housing Programs for Low-Income Households.” In Means-Tested Transfer Programs in the United States, ed. Robert A. Moffitt, 365-442. Chicago, IL: The University of Chicago Press.

Paxson, Christina, and Norbert Schady. 2008. "Cognitive Development Among Young Children in Ecuador: The Roles of Wealth, Health and Parenting." Journal of Human Resources 42(1): 801-7.

Pollit, Ernesto. 1990. Malnutrition and Infection in the Classroom. Paris, France: UNESCO.

Radloff, Linore S. 1977. "The CES-D Scale: A Self-Report Depression Scale for Research in the General Population.” Applied Psychological Measurement 1: 385-401.

Shonkoff, Jack P., and Deborah A. Phillips. 2000. From Neurons to Neighborhoods: The Science of Early Childhood Development. Washington, D.C.: National Academies Press.

Shore, Rima. 1997. Re-thinking the Brain: New Insights into Early Development. New York, NY: Families and Work Institute.

Sternberg, Robert J. 1985. Beyond IQ: A Triarchic Theory of Human Intelligence. Cambridge, UK: Cambridge University Press.

Rivera, Juan A., Daniela Sotres-Alvarez, Jean-Pierre Habicht, Teresa Shamah and Salvador Villalpando. 2004. "Impact of the Mexican program for education, health, and nutrition (PROGRESA) on rates of growth and anemia in infants and young children: a randomized effectiveness study." Journal of the American Medical Association 291: 2563-70.

Secretaria de Desarrollo Social de Coahuila. 2004. Program Operations Manual "Inv. 2004 SEDESOL”. Mexico: SEDESOL.

Secretaria de Desarrollo Social de Coahuila. 2005. Piso Firme - Un Beneficio Muy Concreto. Mexico: SEDESOL.

Takeuchi, Akie, Maureen Cropper, and Antonio Bento. 2006. “The Welfare Effects of Slum Improvement Programs: The Case of Mumbai.” World Bank Policy Research Working Paper 3852.

Tan, Kevin S. W., Mulkit Singh, and Eu Hian Yap. 2002. "Recent Advances in Blastocystis Hominis Research: Hot Spots in Terra Incognita.” International Journal of Parasitology 32(7): 789-804.

Thomson, Hilary, Mark Petticrew, and David Morrison. 2001. "Health Effects on Housing Improvement: Systematic Review of Intervention Studies.” British Medical Journal 321: 187-90.

Umbel, Vivian M., Barbara Z. Pearson, María C. Fernández and D. K. Oller. 1992. “Measuring Bilingual Children’s Receptive Vocabularies.” Child Development 63(4): 1012-20.

World Bank. 2002. World Development Indicators. Washington, D.C.: The World Bank.

World Bank. 2005. World Development Indicators. Washington, D.C.: The World Bank. 
Table 1: Description of Outcome Variables and Sample Sizes in 2005 Survey.

\begin{tabular}{|c|c|c|c|}
\hline Variable & Description & $\begin{array}{c}\text { Observations } \\
\text { Treatment } \\
\end{array}$ & $\begin{array}{c}\text { Observations } \\
\text { Control }\end{array}$ \\
\hline Share of rooms with cement floors & Share of rooms in house with cement floors. & 1,362 & 1,393 \\
\hline Cement floor in kitchen & Indicator equal to one if kitchen has cement floor. & 1,362 & 1,393 \\
\hline Cement floor in dining room & Indicator equal to one if dining room has cement floor. & 1,362 & 1,393 \\
\hline Cement floor in bathroom & Indicator equal to one if bathroom has cement floor. & 1,362 & 1,393 \\
\hline Cement floor in bedroom & Indicator equal to one if bedroom has cement floor. & 1,362 & 1,393 \\
\hline Parasite count & Parasites count present in child's stool sample. & 1,528 & 1,566 \\
\hline Diarrhea & $\begin{array}{l}\text { Indicator equal to one if the mother reports that the child } \\
\text { had diarrhea in the last four weeks. }\end{array}$ & 1,930 & 2,105 \\
\hline Anemia & $\begin{array}{l}\text { Indicator equal to one if the child's hemoglobin level is } \\
\text { less than } 11 \mathrm{~g} / \mathrm{dL} \text {, adjusted for altitude. }\end{array}$ & 1,768 & 1,951 \\
\hline $\begin{array}{l}\text { McArthur Communication } \\
\text { Development Test score }\end{array}$ & $\begin{array}{l}\text { McArthur Communicative Development Test for children } \\
\text { aged } 12 \text { - } 30 \text { months. }\end{array}$ & 291 & 302 \\
\hline $\begin{array}{l}\text { Picture Peabody Vocabulary Test } \\
\text { percentile score }\end{array}$ & $\begin{array}{l}\text { Picture Peabody Vocabulary Test results in terms of the } \\
\text { percentile of the distribution of Latin American outcomes } \\
\text { for children aged } 36 \text { - } 71 \text { months. }\end{array}$ & 757 & 817 \\
\hline Height-for-age z-score & Child's height-for-age z-score. & 1,865 & 2,053 \\
\hline Weight-for-height z-score & Child's weight-for-height z-score. & 1,881 & 2,058 \\
\hline Satisfaction with floor quality & $\begin{array}{l}\text { Indicator equal to one if respondent reports being } \\
\text { satisfied or very satisfied with quality of house's floors. }\end{array}$ & 1,362 & 1,393 \\
\hline Satisfaction with house quality & $\begin{array}{l}\text { Indicator equal to one if respondent reports being } \\
\text { satisfied or very satisfied with overall quality of house. }\end{array}$ & 1,362 & 1,393 \\
\hline Satisfaction with quality of life & $\begin{array}{l}\text { Indicator equal to one if the respondent reports being } \\
\text { satisfied or very satisfied with their overall quality of life. }\end{array}$ & 1,362 & 1,393 \\
\hline Depression Scale (CES-D Scale) & $\begin{array}{l}\text { Radloff (1977) index of self-reported depressive } \\
\text { symptomatology. Range: } 0 \text { (low) to } 60 \text { (high). }\end{array}$ & 1,354 & 1,388 \\
\hline Perceived Stress Scale (PSS) & $\begin{array}{l}\text { Cohen, Kamarck and Mermelstein (1983) index of self- } \\
\text { reported perceived stress symptoms. Range: } 0 \text { (low) to } 40 \\
\text { (high). }\end{array}$ & 1,359 & 1,387 \\
\hline Respiratory diseases & $\begin{array}{l}\text { Indicator equal to one if the mother reports that the child } \\
\text { had a respiratory disease in the last four weeks. }\end{array}$ & 1,930 & 2,107 \\
\hline Skin diseases & $\begin{array}{l}\text { Indicator equal to one if the mother reports that the child } \\
\text { had a skin disease in the last four weeks. }\end{array}$ & 1,926 & 2,106 \\
\hline Other diseases & $\begin{array}{l}\text { Indicator equal to one if the mother reports that the child } \\
\text { had another disease in the last four weeks. }\end{array}$ & 1,930 & 2,106 \\
\hline Installation of cement floor & $\begin{array}{l}\text { Indicator equal to one if the household reports having } \\
\text { installed a cement floor since } 2000 \text {. }\end{array}$ & 1,362 & 1,392 \\
\hline Construction of sanitation facilities & $\begin{array}{l}\text { Indicator equal to one if the household reports having } \\
\text { constructed new sanitation facilities since } 2000 \text {. }\end{array}$ & 1,362 & 1,390 \\
\hline Restoration of sanitation facilities & $\begin{array}{l}\text { Indicator equal to one if the household reports having } \\
\text { improved sanitation facilities since } 2000 \text {. }\end{array}$ & 1,362 & 1,391 \\
\hline Construction of ceiling & $\begin{array}{l}\text { Indicator equal to one if the household reports having } \\
\text { installed new ceilings since } 2000 \text {. }\end{array}$ & 1,361 & 1,392 \\
\hline Restoration of walls & $\begin{array}{l}\text { Indicator equal to one if the household reports having } \\
\text { improved house walls since } 2000 \text {. }\end{array}$ & 1,362 & 1,392 \\
\hline Any improvement & $\begin{array}{l}\text { Indicator equal to one if the household reports having any } \\
\text { of the house improvements reported above, excluding } \\
\text { Installation of cement floor, since } 2000 \text {. }\end{array}$ & 1,362 & 1,393 \\
\hline $\begin{array}{l}\text { Log of self-reported rental value of } \\
\text { house }\end{array}$ & Logarithm of self-reported rental value of the house. & 1,284 & 1,285 \\
\hline $\begin{array}{l}\text { Log of self-reported sale value of } \\
\text { house }\end{array}$ & Logarithm of self-reported sale value of the house. & 1,239 & 1,223 \\
\hline $\begin{array}{l}\text { Log total income of mothers of } \\
\text { children } 0-5 \text { yrs }\end{array}$ & $\begin{array}{l}\text { Logarithm of total income of mothers of children from } 0 \\
\text { to } 5 \text { years of age. }\end{array}$ & 247 & 301 \\
\hline $\begin{array}{l}\text { Log total income of fathers of } \\
\text { children } 0-5 \text { yrs }\end{array}$ & $\begin{array}{l}\text { Logarithm of total income of fathers of children from } 0 \text { to } \\
5 \text { years of age. }\end{array}$ & 1,026 & 1,000 \\
\hline Total consumption per capita & Total consumption per capita reported by the household. & 1,360 & 1,391 \\
\hline
\end{tabular}


Table 2: Difference of Means for Pre-intervention 2000 Census Variables. ${ }^{\text {a }}$

\begin{tabular}{|c|c|c|c|}
\hline Variable & $\begin{array}{c}\text { Mean } \\
\text { Treatment }\end{array}$ & $\begin{array}{c}\text { Mean } \\
\text { Control } \\
\end{array}$ & $\begin{array}{c}\text { Mean } \\
\text { Difference }\end{array}$ \\
\hline Proportion of blocks of houses with at least one house that has dirt floors & $\begin{array}{c}0.573 \\
(0.030)\end{array}$ & $\begin{array}{c}0.612 \\
(0.042)\end{array}$ & $\begin{array}{c}-0.040 \\
(0.051)\end{array}$ \\
\hline Proportion of households with dirt floors & $\begin{array}{c}0.173 \\
(0.026)\end{array}$ & $\begin{array}{c}0.189 \\
(0.026)\end{array}$ & $\begin{array}{l}-0.016 \\
(0.037)\end{array}$ \\
\hline Average number of children between 0 and 5 yrs of age & $\begin{array}{c}0.710 \\
(0.014)\end{array}$ & $\begin{array}{c}0.721 \\
(0.014)\end{array}$ & $\begin{array}{c}-0.011 \\
(0.020)\end{array}$ \\
\hline Number of households & $\begin{array}{l}511.292 \\
(60.381)\end{array}$ & $\begin{array}{l}488.989 \\
(38.105)\end{array}$ & $\begin{array}{c}22.303 \\
(71.399)\end{array}$ \\
\hline Number of people & $\begin{array}{l}2241.586 \\
(280.400)\end{array}$ & $\begin{array}{l}2170.597 \\
(172.460)\end{array}$ & $\begin{array}{c}70.989 \\
(329.191)\end{array}$ \\
\hline Average number of rooms per household & $\begin{array}{c}2.352 \\
(0.069)\end{array}$ & $\begin{array}{c}2.353 \\
(0.075)\end{array}$ & $\begin{array}{l}-0.002 \\
(0.102)\end{array}$ \\
\hline Average number of people per household & $\begin{array}{c}4.326 \\
(0.033)\end{array}$ & $\begin{array}{c}4.448 \\
(0.109)\end{array}$ & $\begin{array}{c}-0.122 \\
(0.114)\end{array}$ \\
\hline Proportion of households with no water connection outside the house & $\begin{array}{c}0.076 \\
(0.018)\end{array}$ & $\begin{array}{c}0.043 \\
(0.014)\end{array}$ & $\begin{array}{c}0.033 \\
(0.023)\end{array}$ \\
\hline Proportion of households with no water connection inside the house & $\begin{array}{c}0.392 \\
(0.038)\end{array}$ & $\begin{array}{c}0.316 \\
(0.036)\end{array}$ & $\begin{array}{c}0.076 \\
(0.052)\end{array}$ \\
\hline Proportion of households with no water connection in the bathroom & $\begin{array}{c}0.507 \\
(0.040)\end{array}$ & $\begin{array}{c}0.451 \\
(0.032)\end{array}$ & $\begin{array}{c}0.056 \\
(0.052)\end{array}$ \\
\hline Proportion of households with no gas heater & $\begin{array}{c}0.028 \\
(0.004)\end{array}$ & $\begin{array}{c}0.029 \\
(0.004)\end{array}$ & $\begin{array}{c}-0.001 \\
(0.006)\end{array}$ \\
\hline Proportion of households with no refrigerator & $\begin{array}{c}0.204 \\
(0.018)\end{array}$ & $\begin{array}{c}0.212 \\
(0.013)\end{array}$ & $\begin{array}{l}-0.007 \\
(0.022)\end{array}$ \\
\hline Proportion of households with no washing machine & $\begin{array}{c}0.379 \\
(0.018)\end{array}$ & $\begin{array}{c}0.359 \\
(0.018)\end{array}$ & $\begin{array}{c}0.020 \\
(0.026)\end{array}$ \\
\hline Proportion of households with no telephone & $\begin{array}{c}0.804 \\
(0.014)\end{array}$ & $\begin{array}{c}0.786 \\
(0.020)\end{array}$ & $\begin{array}{c}0.018 \\
(0.025)\end{array}$ \\
\hline Proportion of households with no vehicle & $\begin{array}{c}0.735 \\
(0.014)\end{array}$ & $\begin{array}{c}0.734 \\
(0.018)\end{array}$ & $\begin{array}{c}0.000 \\
(0.023)\end{array}$ \\
\hline Average overcrowding index & $\begin{array}{c}2.302 \\
(0.063)\end{array}$ & $\begin{array}{c}2.314 \\
(0.069)\end{array}$ & $\begin{array}{c}-0.012 \\
(0.094)\end{array}$ \\
\hline Proportion of households below the poverty line & $\begin{array}{c}0.140 \\
(0.015)\end{array}$ & $\begin{array}{c}0.148 \\
(0.012)\end{array}$ & $\begin{array}{c}-0.009 \\
(0.019)\end{array}$ \\
\hline Proportion of households with illiterate members & $\begin{array}{c}0.063 \\
(0.003)\end{array}$ & $\begin{array}{c}0.059 \\
(0.004)\end{array}$ & $\begin{array}{c}0.004 \\
(0.005)\end{array}$ \\
\hline Average years of schooling of head of household & $\begin{array}{c}6.386 \\
(0.097)\end{array}$ & $\begin{array}{c}6.514 \\
(0.166)\end{array}$ & $\begin{array}{c}-0.128 \\
(0.192)\end{array}$ \\
\hline Average number of school dropouts among children aged 5 - 15 yrs & $\begin{array}{c}0.180 \\
(0.008)\end{array}$ & $\begin{array}{c}0.172 \\
(0.009)\end{array}$ & $\begin{array}{c}0.007 \\
(0.012)\end{array}$ \\
\hline Average number of household members who work & $\begin{array}{c}1.508 \\
(0.026)\end{array}$ & $\begin{array}{c}1.592 \\
(0.064)\end{array}$ & $\begin{array}{c}-0.084 \\
(0.069)\end{array}$ \\
\hline Average number of family members who earn an income & $\begin{array}{c}1.422 \\
(0.025)\end{array}$ & $\begin{array}{c}1.495 \\
(0.060)\end{array}$ & $\begin{array}{c}-0.072 \\
(0.065)\end{array}$ \\
\hline Number of observations & 599 & 370 & \\
\hline
\end{tabular}


Table 3: Difference of Means for Independent Variables in 2005 Survey.

\begin{tabular}{|c|c|c|c|c|c|}
\hline Variable & $\begin{array}{c}\text { Observations } \\
\text { Treatment }\end{array}$ & $\begin{array}{c}\text { Mean } \\
\text { Treatment }\end{array}$ & $\begin{array}{c}\text { Observations } \\
\text { Control }\end{array}$ & $\begin{array}{c}\text { Mean } \\
\text { Control } \\
\end{array}$ & $\begin{array}{c}\text { Mean } \\
\text { Difference }\end{array}$ \\
\hline \multicolumn{6}{|l|}{ Household Demographics } \\
\hline Number of household members & 1,362 & $\begin{array}{c}5.320 \\
(0.070)\end{array}$ & 1,393 & $\begin{array}{c}5.374 \\
(0.071)\end{array}$ & $\begin{array}{l}-0.054 \\
(0.100)\end{array}$ \\
\hline Head of household's age & 1,362 & $\begin{array}{l}37.537 \\
(0.413)\end{array}$ & 1,393 & $\begin{array}{l}37.120 \\
(0.490)\end{array}$ & $\begin{array}{c}0.418 \\
(0.641)\end{array}$ \\
\hline Head of household's years of schooling & 1,360 & $\begin{array}{c}6.128 \\
(0.134)\end{array}$ & 1,391 & $\begin{array}{c}6.408 \\
(0.115)\end{array}$ & $\begin{array}{l}-0.280 \\
(0.177)\end{array}$ \\
\hline Spouse's age & 1,362 & $\begin{array}{l}29.645 \\
(0.475)\end{array}$ & 1,393 & $\begin{array}{l}28.772 \\
(0.406)\end{array}$ & $\begin{array}{c}0.874 \\
(0.625)\end{array}$ \\
\hline Spouse's years of schooling & 1,207 & $\begin{array}{c}6.338 \\
(0.150)\end{array}$ & 1,211 & $\begin{array}{c}6.479 \\
(0.108)\end{array}$ & $\begin{array}{l}-0.141 \\
(0.185)\end{array}$ \\
\hline \multicolumn{6}{|l|}{ Characteristics of Children Aged 0-5 } \\
\hline Age & 1,940 & $\begin{array}{c}2.643 \\
(0.032)\end{array}$ & 2,112 & $\begin{array}{c}2.579 \\
(0.032)\end{array}$ & $\begin{array}{c}0.064 \\
(0.046)\end{array}$ \\
\hline Male (=1) & 1,940 & $\begin{array}{c}0.492 \\
(0.011)\end{array}$ & 2,112 & $\begin{array}{c}0.517 \\
(0.007)\end{array}$ & $\begin{array}{l}-0.024^{*} \\
(0.013)\end{array}$ \\
\hline $\begin{array}{l}\text { Mother of at least one child in household } \\
\text { present }(=1)\end{array}$ & 1,940 & $\begin{array}{c}0.968 \\
(0.005)\end{array}$ & 2,112 & $\begin{array}{c}0.964 \\
(0.005)\end{array}$ & $\begin{array}{c}0.004 \\
(0.007)\end{array}$ \\
\hline Mother's age (if present) & 1,861 & $\begin{array}{l}27.383 \\
(0.187)\end{array}$ & 1,992 & $\begin{array}{l}27.465 \\
(0.169)\end{array}$ & $\begin{array}{l}-0.082 \\
(0.252)\end{array}$ \\
\hline Mother's years of schooling (if present) & 1,859 & $\begin{array}{c}7.059 \\
(0.135)\end{array}$ & 1,992 & $\begin{array}{c}6.910 \\
(0.133)\end{array}$ & $\begin{array}{c}0.149 \\
(0.189)\end{array}$ \\
\hline $\begin{array}{l}\text { Father of at least one child in household } \\
\text { present }(=1)\end{array}$ & 1,940 & $\begin{array}{c}0.797 \\
(0.011)\end{array}$ & 2,112 & $\begin{array}{c}0.763 \\
(0.013)\end{array}$ & $\begin{array}{l}0.034^{*} \\
(0.017)\end{array}$ \\
\hline Father's age (if present) & 1,480 & $\begin{array}{l}30.368 \\
(0.303)\end{array}$ & 1,525 & $\begin{array}{l}30.632 \\
(0.271)\end{array}$ & $\begin{array}{l}-0.265 \\
(0.407)\end{array}$ \\
\hline Father's years of schooling (if present) & 1,476 & $\begin{array}{c}6.839 \\
(0.155)\end{array}$ & 1,519 & $\begin{array}{c}7.153 \\
(0.117)\end{array}$ & $\begin{array}{c}-0.313 \\
(0.194)\end{array}$ \\
\hline \multicolumn{6}{|l|}{ Housing Characteristics } \\
\hline Number of rooms & 1,362 & $\begin{array}{c}2.080 \\
(0.054)\end{array}$ & 1,393 & $\begin{array}{c}1.981 \\
(0.053)\end{array}$ & $\begin{array}{c}0.099 \\
(0.076)\end{array}$ \\
\hline Water connection $(=1)$ & 1,362 & $\begin{array}{c}0.970 \\
(0.005)\end{array}$ & 1,393 & $\begin{array}{c}0.977 \\
(0.005)\end{array}$ & $\begin{array}{l}-0.007 \\
(0.007)\end{array}$ \\
\hline Water connection inside the house $(=1)$ & 1,362 & $\begin{array}{c}0.511 \\
(0.029)\end{array}$ & 1,393 & $\begin{array}{c}0.546 \\
(0.022)\end{array}$ & $\begin{array}{l}-0.035 \\
(0.036)\end{array}$ \\
\hline Electricity $(=1)$ & 1,362 & $\begin{array}{c}0.985 \\
(0.005)\end{array}$ & 1,393 & $\begin{array}{c}0.993 \\
(0.002)\end{array}$ & $\begin{array}{l}-0.008 \\
(0.005)\end{array}$ \\
\hline Share of rooms with cement floors in 2000 & 1,362 & $\begin{array}{c}0.330 \\
(0.020)\end{array}$ & 1,393 & $\begin{array}{c}0.327 \\
(0.021)\end{array}$ & $\begin{array}{c}0.003 \\
(0.029)\end{array}$ \\
\hline \multicolumn{6}{|l|}{ Hygienic Environment } \\
\hline Household has animals on land $(=1)$ & 1,362 & $\begin{array}{c}0.517 \\
(0.014)\end{array}$ & 1,393 & $\begin{array}{c}0.480 \\
(0.018)\end{array}$ & $\begin{array}{c}0.037 \\
(0.023)\end{array}$ \\
\hline Animals allowed to enter the house $(=1)$ & 1,362 & $\begin{array}{c}0.192 \\
(0.014)\end{array}$ & 1,393 & $\begin{array}{c}0.190 \\
(0.013)\end{array}$ & $\begin{array}{c}0.002 \\
(0.020)\end{array}$ \\
\hline Uses garbage collection service $(=1)$ & 1,362 & $\begin{array}{c}0.799 \\
(0.030)\end{array}$ & 1,393 & $\begin{array}{c}0.845 \\
(0.033)\end{array}$ & $\begin{array}{l}-0.046 \\
(0.045)\end{array}$ \\
\hline $\begin{array}{l}\text { Number of times respondent washed hand } \\
\text { the day before }\end{array}$ & 1,362 & $\begin{array}{c}3.754 \\
(0.057)\end{array}$ & 1,393 & $\begin{array}{l}3.716 \\
(0.060)\end{array}$ & $\begin{array}{c}0.038 \\
(0.083)\end{array}$ \\
\hline
\end{tabular}


Table 3: continued.

\begin{tabular}{|c|c|c|c|c|c|}
\hline Variable & $\begin{array}{c}\text { Observations } \\
\text { Treatment } \\
\end{array}$ & $\begin{array}{c}\text { Mean } \\
\text { Treatment }\end{array}$ & $\begin{array}{c}\text { Observations } \\
\text { Control }\end{array}$ & $\begin{array}{c}\text { Mean } \\
\text { Control } \\
\end{array}$ & $\begin{array}{c}\text { Mean } \\
\text { Difference } \\
\end{array}$ \\
\hline \multicolumn{6}{|l|}{ Economic Characteristics } \\
\hline Total household income per capita & 1,361 & $\begin{array}{l}1024.703 \\
(71.168)\end{array}$ & 1,391 & $\begin{array}{l}1051.676 \\
(102.976)\end{array}$ & $\begin{array}{c}-26.973 \\
(125.176)\end{array}$ \\
\hline Total value of household assets per capita & 1,361 & $\begin{array}{r}22393.733 \\
(254.334)\end{array}$ & 1,393 & $\begin{array}{r}22032.320 \\
(308.994)\end{array}$ & $\begin{array}{c}361.414 \\
(400.204)\end{array}$ \\
\hline \multicolumn{6}{|l|}{ Public Social Programs } \\
\hline $\begin{array}{l}\text { Cash transfers per capita from government } \\
\text { programs }\end{array}$ & 1,361 & $\begin{array}{l}16.187 \\
(2.094)\end{array}$ & 1,392 & $\begin{array}{l}12.604 \\
(1.222)\end{array}$ & $\begin{array}{l}3.583 \\
(2.425)\end{array}$ \\
\hline $\begin{array}{l}\text { Household beneficiary of government milk } \\
\text { supplement program }(=1)\end{array}$ & 1,362 & $\begin{array}{c}0.060 \\
(0.009)\end{array}$ & 1,393 & $\begin{array}{c}0.082 \\
(0.011)\end{array}$ & $\begin{array}{l}-0.022 \\
(0.015)\end{array}$ \\
\hline $\begin{array}{l}\text { Household beneficiary of government food } \\
\text { program }(=1)\end{array}$ & 1,362 & $\begin{array}{c}0.037 \\
(0.007) \\
\end{array}$ & 1,393 & $\begin{array}{c}0.022 \\
(0.007) \\
\end{array}$ & $\begin{array}{c}0.015 \\
(0.009) \\
\end{array}$ \\
\hline
\end{tabular}

${ }^{\mathrm{a}}$ Table computed at household level and individual level using survey information. Total household income per capita excludes 3 observations with values greater than \$450,000 (US\$ 45,000 approximately). All the results in the paper remain unchanged if these observations are included in the analysis. Share of rooms with cement floors in 2000 is a self-declared retrospective variable that refers to the year 2000, while all the other variables are contemporaneous with the time of the survey. Standard errors clustered at census-block level shown in parentheses (136 clusters). Data source: 2005 Survey.

*Significantly different from 0 at 10 -percent level. ${ }^{* *}$ Significantly different from 0 at 5 -percent level. ***Significantly different from 0 at 1-percent level. 
Table 4: Regressions of Cement Floor Coverage Measures on Program Dummy. ${ }^{\text {a }}$

\begin{tabular}{|c|c|c|c|c|}
\hline Dependent Variable & $\begin{array}{c}\text { Control Group } \\
\text { Mean (Std. Dev.) }\end{array}$ & Model 1 & Model 2 & Model 3 \\
\hline \multirow{3}{*}{ Share of rooms with cement floors } & & 0.202 & 0.208 & 0.210 \\
\hline & & {$[0.021]^{* * *}$} & {$[0.019]^{* * *}$} & {$[0.019]^{* * *}$} \\
\hline & $0.728(0.363)$ & 27.746 & 28.512 & 28.876 \\
\hline \multirow[t]{3}{*}{ Cement floor in kitchen } & & 0.255 & 0.260 & 0.265 \\
\hline & & {$[0.025]^{* * *}$} & {$[0.023]^{* * *}$} & {$[0.023]^{* * *}$} \\
\hline & $0.671(0.470)$ & 37.936 & 38.708 & 39.440 \\
\hline \multirow[t]{3}{*}{ Cement floor in dining room } & & 0.21 & 0.217 & 0.221 \\
\hline & & {$[0.026]^{* * *}$} & {$[0.025]^{* * *}$} & {$[0.025]^{* * *}$} \\
\hline & $0.709(0.455)$ & 29.633 & 30.588 & 31.189 \\
\hline \multirow[t]{3}{*}{ Cement floor in bathroom } & & 0.105 & 0.113 & 0.117 \\
\hline & & {$[0.022]^{* * *}$} & {$[0.018]^{* * *}$} & {$[0.018]^{* * *}$} \\
\hline & $0.803(0.398)$ & 13.071 & 14.043 & 14.536 \\
\hline \multirow{3}{*}{ Cement floor in bedroom } & & 0.238 & 0.245 & 0.245 \\
\hline & & {$[0.020]^{* * *}$} & {$[0.021]^{* * *}$} & {$[0.020]^{* * *}$} \\
\hline & $0.668(0.471)$ & 35.598 & 36.735 & 36.695 \\
\hline
\end{tabular}

${ }^{\mathrm{a}}$ Regressions computed using survey information (sample sizes reported in Table 1). Missing values in covariates were imputed with zero, and a corresponding dummy variable was then added to the regressions. Model 1: no controls; Model 2: age, demographic, and health-habits controls; Model 3: age, demographic, health-habits and public social programs controls. Reported results: estimated coefficient, clustered standard error at census-block level in brackets (136 clusters), and 100*coefficient/control mean. Data source: 2005 Survey.

*Significantly different from 0 at 10 -percent level. **Significantly different from 0 at 5-percent level. ***Significantly different from 0 at 1-percent level. 
Table 5: Regressions of Children's Health Measures on Program Dummy. ${ }^{\text {a }}$

\begin{tabular}{|c|c|c|c|c|}
\hline Dependent Variable & $\begin{array}{c}\text { Control Group } \\
\text { Mean (Std. Dev.) }\end{array}$ & Model 1 & Model 2 & Model 3 \\
\hline \multirow[t]{3}{*}{ Parasite count } & & -0.065 & -0.064 & -0.064 \\
\hline & & {$[0.032]^{* *}$} & {$[0.031]^{* *}$} & {$[0.032]^{* *}$} \\
\hline & $0.333(0.673)$ & -19.545 & -19.345 & -19.198 \\
\hline \multirow[t]{3}{*}{ Diarrhea } & & -0.018 & -0.020 & -0.018 \\
\hline & & {$[0.009]^{*}$} & {$[0.009]^{* *}$} & {$[0.09]^{*}$} \\
\hline & $0.142(0.349)$ & -12.819 & -13.834 & -12.803 \\
\hline \multirow{3}{*}{ Anemia } & & -0.085 & -0.081 & -0.083 \\
\hline & & {$[0.028]^{* * *}$} & {$[0.027] * * *$} & {$[0.027]^{* * *}$} \\
\hline & $0.426(0.495)$ & -20.059 & -18.908 & -19.388 \\
\hline McArthur Communication & & 4.031 & 5.652 & 5.557 \\
\hline \multirow[t]{2}{*}{ Development Test score } & & {$[1.650]^{* *}$} & {$[1.642]^{* * *}$} & {$[1.641]^{* * *}$} \\
\hline & $13.354(18.952)$ & 30.182 & 42.325 & 41.609 \\
\hline \multirow{3}{*}{$\begin{array}{l}\text { Picture Peabody Vocabulary Test } \\
\text { percentile score }\end{array}$} & & 2.668 & 3.206 & 3.083 \\
\hline & & [1.689] & {$[1.430]^{* *}$} & {$[1.410]^{* *}$} \\
\hline & $30.656(24.864)$ & 8.702 & 10.460 & 10.058 \\
\hline \multirow[t]{3}{*}{ Height-for-age z-score } & & 0.007 & -0.002 & 0.002 \\
\hline & & [0.043] & {$[0.038]$} & [0.039] \\
\hline & $-0.605(1.104)$ & -1.161 & 0.279 & -0.323 \\
\hline \multirow[t]{3}{*}{ Weight-for-height z-score } & & 0.002 & -0.005 & -0.011 \\
\hline & & [0.034] & {$[0.036]$} & {$[0.037]$} \\
\hline & $0.125(1.133)$ & 1.790 & -4.119 & -8.727 \\
\hline \multicolumn{5}{|c|}{$\begin{array}{l}{ }^{a} \text { Regressions computed using survey information (sample sizes reported in Table 1). Missing values in covariates were imputed } \\
\text { with zero, and a corresponding dummy variable was then added to the regressions. Model 1: no controls; Model 2: age, } \\
\text { demographic, and health-habits controls; Model 3: age, demographic, health-habits and public social programs controls. Reported } \\
\text { results: estimated coefficient, clustered standard error at census-block level in brackets (136 clusters), and 100*coefficient/control } \\
\text { mean. Data source: } 2005 \text { Survey. }\end{array}$} \\
\hline
\end{tabular}


Table 6: Regressions of Satisfaction and Maternal Mental Health Measures on Program Dummy. ${ }^{\text {a }}$

\begin{tabular}{|c|c|c|c|c|}
\hline Dependent Variable & $\begin{array}{c}\text { Control Group } \\
\text { Mean (Std. Dev.) }\end{array}$ & Model 1 & Model 2 & Model 3 \\
\hline \multirow[t]{3}{*}{ Satisfaction with floor quality } & & 0.219 & 0.223 & 0.222 \\
\hline & & {$[0.023]^{* * *}$} & {$[0.024]^{* * *}$} & {$[0.026]^{* * *}$} \\
\hline & $0.511(0.500)$ & 42.784 & 43.635 & 43.421 \\
\hline \multirow[t]{3}{*}{ Satisfaction with house quality } & & 0.092 & 0.087 & 0.084 \\
\hline & & {$[0.021]^{* * *}$} & {$[0.021]^{* * *}$} & {$[0.022]^{* * *}$} \\
\hline & $0.605(0.489)$ & 15.136 & 14.369 & 13.892 \\
\hline \multirow[t]{3}{*}{ Satisfaction with quality of life } & & 0.112 & 0.112 & 0.112 \\
\hline & & {$[0.022]^{* * *}$} & {$[0.021]^{* * *}$} & {$[0.022]^{* * *}$} \\
\hline & $0.601(0.490)$ & 18.650 & 18.557 & 18.701 \\
\hline \multirow[t]{3}{*}{ Depression Scale (CES-D Scale) } & & -2.315 & -2.417 & -2.372 \\
\hline & & {$[0.616] * * *$} & {$[0.570]^{* * *}$} & {$[0.562]^{* * *}$} \\
\hline & $18.532(9.402)$ & -12.493 & -13.043 & -12.797 \\
\hline \multirow[t]{3}{*}{ Perceived Stress Scale (PSS) } & & -1.751 & -1.769 & -1.742 \\
\hline & & {$[0.428]^{* * *}$} & {$[0.396]^{* * *}$} & {$[0.396]^{* * *}$} \\
\hline & $16.514(6.914)$ & -10.603 & -10.710 & -10.551 \\
\hline
\end{tabular}

${ }^{\mathrm{a}}$ Regressions computed using survey information (sample sizes reported in Table 1). Missing values in covariates were imputed with zero, and a corresponding dummy variable was then added to the regressions. Model 1: no controls; Model 2: age, demographic, and health-habits controls; Model 3: age, demographic, health-habits and public social programs controls. Reported results: estimated coefficient, clustered standard error at census-block level in brackets (136 clusters), and 100*coefficient/control mean. Data source: 2005 Survey.

*Significantly different from 0 at 10 -percent level. **Significantly different from 0 at 5-percent level. ***Significantly different from 0 at 1-percent level. 
Table 7: Robustness Checks. ${ }^{a}$

\begin{tabular}{|c|c|c|c|c|}
\hline Dependent Variable & $\begin{array}{c}\text { Control Group } \\
\text { Mean (Std. Dev.) }\end{array}$ & Model 1 & Model 2 & Model 3 \\
\hline \multirow[t]{3}{*}{ Respiratory diseases } & & 0.021 & 0.019 & 0.017 \\
\hline & & [0.019] & [0.018] & {$[0.019]$} \\
\hline & $0.355(0.479)$ & 5.819 & 5.286 & 4.762 \\
\hline \multirow{3}{*}{ Skin diseases } & & 0.001 & 0.003 & 0.002 \\
\hline & & {$[0.012]$} & {$[0.012]$} & {$[0.012]$} \\
\hline & $0.101(0.302)$ & 1.132 & 2.762 & 2.470 \\
\hline \multirow[t]{3}{*}{ Other diseases } & & 0.006 & 0.007 & 0.007 \\
\hline & & {$[0.009]$} & {$[0.009]$} & {$[0.009]$} \\
\hline & $0.041(0.198)$ & 14.194 & 16.554 & 16.074 \\
\hline \multirow[t]{3}{*}{ Installation of cement floor } & & 0.375 & 0.373 & 0.376 \\
\hline & & {$[0.028]^{* * *}$} & {$[0.028]^{* * *}$} & {$[0.028]^{* * *}$} \\
\hline & $0.530(0.499)$ & 70.753 & 70.374 & 70.860 \\
\hline \multirow[t]{3}{*}{ Construction of sanitation facilities } & & -0.016 & -0.016 & -0.015 \\
\hline & & {$[0.015]$} & [0.015] & {$[0.015]$} \\
\hline & $0.101(0.302)$ & -15.315 & -16.094 & -15.071 \\
\hline \multirow{3}{*}{ Restoration of sanitation facilities } & & -0.001 & -0.001 & -0.002 \\
\hline & & {$[0.013]$} & {$[0.013]$} & {$[0.012]$} \\
\hline & $0.045(0.206)$ & -2.813 & -2.109 & -3.811 \\
\hline \multirow[t]{3}{*}{ Construction of ceiling } & & 0.026 & 0.019 & 0.016 \\
\hline & & {$[0.024]$} & {$[0.024]$} & {$[0.023]$} \\
\hline & $0.160(0.366)$ & 16.099 & 11.659 & 10.287 \\
\hline \multirow[t]{3}{*}{ Restoration of walls } & & 0.012 & 0.012 & 0.014 \\
\hline & & {$[0.017]$} & {$[0.016]$} & {$[0.016]$} \\
\hline & $0.111(0.314)$ & 10.830 & 10.802 & 12.953 \\
\hline \multirow{3}{*}{$\begin{array}{l}\text { Any house expansion (excluding } \\
\text { installation of cement floors) }\end{array}$} & & 0.043 & 0.035 & 0.037 \\
\hline & & {$[0.031]$} & {$[0.031]$} & {$[0.030]$} \\
\hline & $0.277(0.448)$ & 15.524 & 12.787 & 13.272 \\
\hline \multirow{3}{*}{$\begin{array}{l}\text { Log of self-reported rental value } \\
\text { of house }\end{array}$} & & 0.033 & 0.050 & 0.053 \\
\hline & & {$[0.040]$} & [0.032] & [0.031] \\
\hline & $5.918(0.740)$ & 0.555 & 0.853 & 0.899 \\
\hline \multirow{3}{*}{$\begin{array}{l}\text { Log of self-reported sale value } \\
\text { of house }\end{array}$} & & -0.044 & -0.015 & -0.014 \\
\hline & & [0.100] & {$[0.081]$} & {$[0.078]$} \\
\hline & $10.491(1.168)$ & -0.418 & -0.147 & -0.132 \\
\hline \multirow{3}{*}{$\begin{array}{l}\text { Log total income of mothers of } \\
\text { children } 0 \text { - } 5 \text { yrs }\end{array}$} & & -0.037 & -0.034 & -0.029 \\
\hline & & [0.064] & [0.065] & {$[0.066]$} \\
\hline & $7.792(0.665)$ & -0.480 & -0.436 & -0.374 \\
\hline \multirow{3}{*}{$\begin{array}{l}\text { Log total income of fathers of } \\
\text { children } 0 \text { - } 5 \text { yrs }\end{array}$} & & -0.016 & -0.005 & 0.001 \\
\hline & & {$[0.028]$} & {$[0.027]$} & {$[0.026]$} \\
\hline & $8.121(0.592)$ & -0.194 & -0.064 & 0.016 \\
\hline \multirow[t]{3}{*}{ Total consumption per capita } & & 5.217 & 10.682 & 14.012 \\
\hline & & [44.368] & [43.686] & [43.099] \\
\hline & 753.733 (1219.488) & 0.692 & 1.417 & 1.859 \\
\hline
\end{tabular}

${ }^{\mathrm{a}}$ Regressions computed using survey information (sample sizes reported in Table 1). Missing values in covariates were imputed with zero, and a corresponding dummy variable was then added to the regressions. Model 1: no controls; Model 2: age, demographic, and health-habits controls; Model 3: age, demographic, health-habits and public social programs controls. Reported results: estimated coefficient, clustered standard error at census-block level in brackets (136 clusters), and 100*coefficient/control mean. Data source: 2005 Survey.

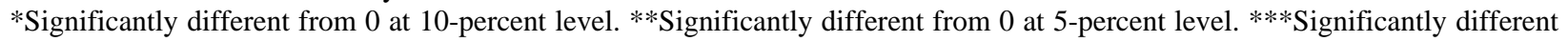
from 0 at 1-percent level. 

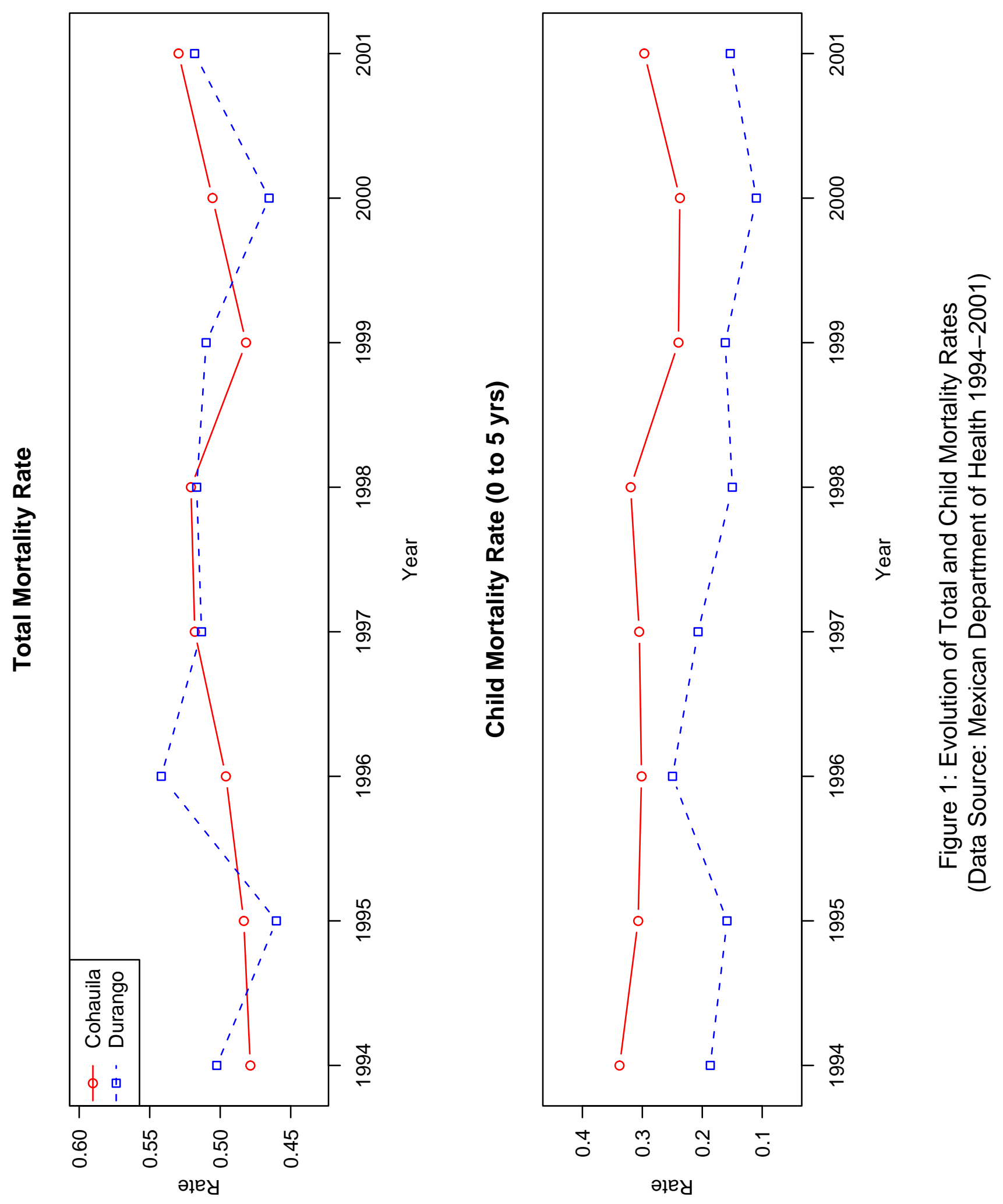

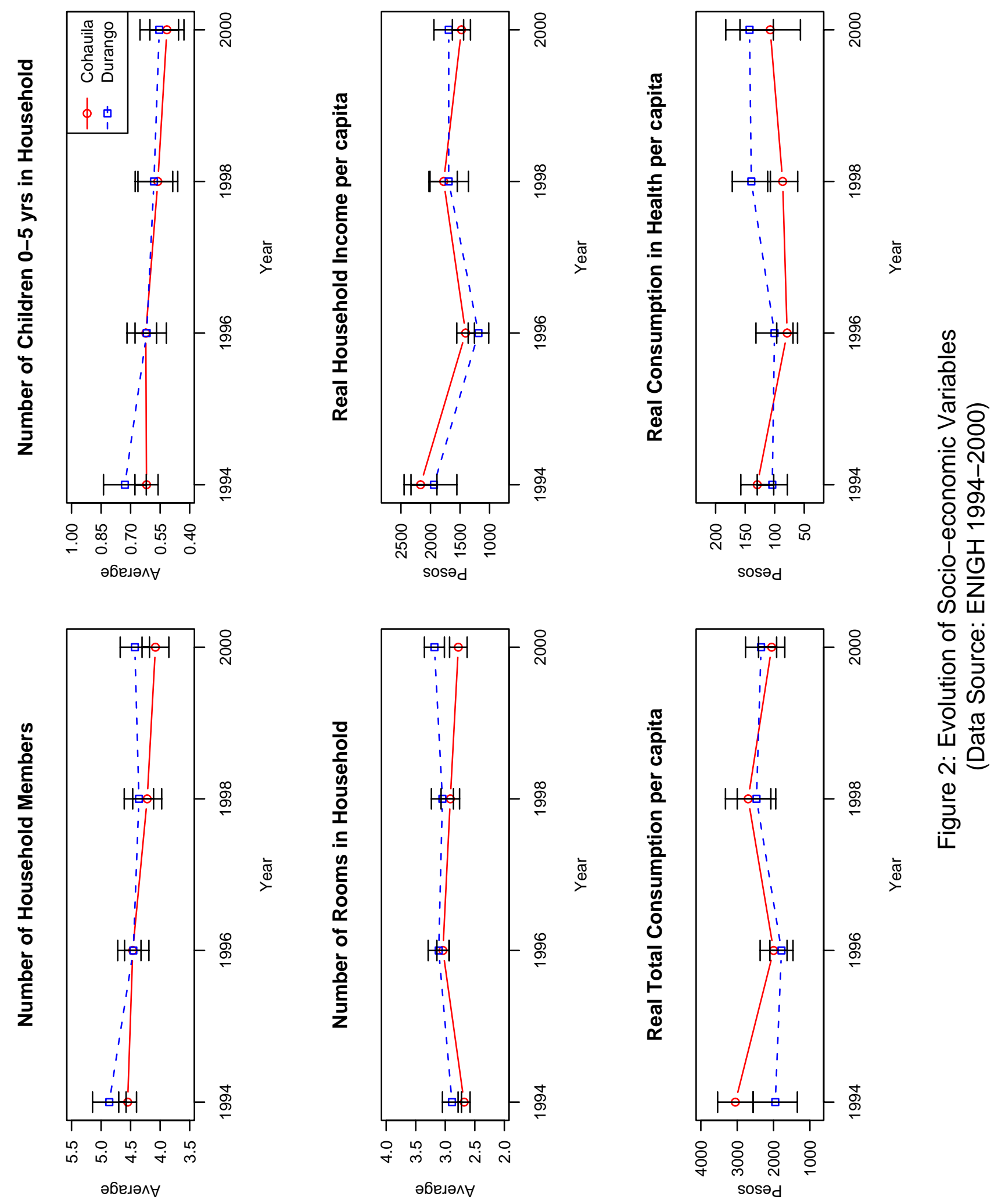


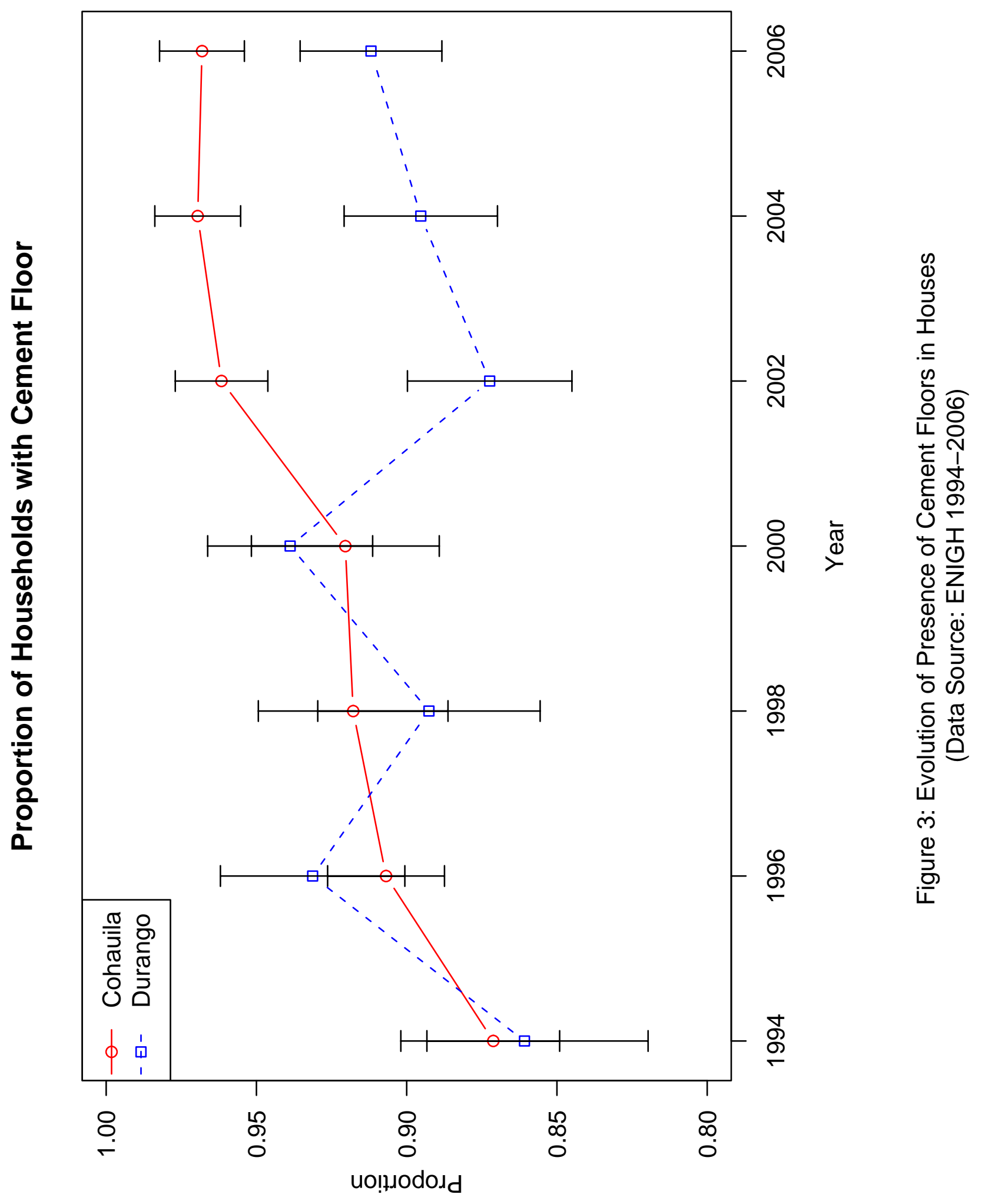




\section{SERIE DOCUMENTOS DE TRABAJO DEL CEDLAS}

Todos los Documentos de Trabajo del CEDLAS están disponibles en formato electrónico en 〈www.depeco.econo.unlp.edu.ar/cedlas〉.

- Nro. 74 (Agosto, 2008). Matias D. Cattaneo, Sebastian Galiani, Paul J. Gertler, Sebastian Martinez y Rocio Titiunik. "Housing, Health and Happiness".

- Nro. 73 (Agosto, 2008). María Laura Alzúa. "Are Informal Workers Secondary Workers?: Evidence for Argentina".

- Nro. 72 (Julio, 2008). Carolina Díaz-Bonilla, Hans Lofgren y Martín Cicowiez. "Public Policies for the MDGs: The Case of the Dominican Republic".

- Nro. 71 (Julio, 2008). Leonardo Gasparini, Facundo Crosta, Francisco Haimovich, Beatriz Alvarez, Andrés Ham y Raúl Sánchez. "Un Piso de Protección Social en América Latina: Costos Fiscales e Impactos Sociales".

- Nro. 70 (Junio, 2008). Mariana Viollaz. "Polarización de ingresos laborales: Argentina 1992-2006".

- Nro. 69 (Mayo, 2008). Mariana Marchionni, Walter Sosa Escudero y Javier Alejo. "Efectos Distributivos de Esquemas Alternativos de Tarifas Sociales: Una Exploración Cuantitativa".

- Nro. 68 (Mayo, 2008). Ricardo N. Bebczuk. "Financial Inclusion in Latin America and the Caribbean: Review and Lessons".

- Nro. 67 (Abril, 2008). Mariana Marchionni, Walter Sosa Escudero y Javier Alejo. "La Incidencia Distributiva del Acceso, Gasto y Consumo de los Servicios Públicos".

- Nro. 66 (Abril, 2008). Ricardo N. Bebczuk. "Dolarización y Pobreza en Ecuador".

- Nro. 65 (Marzo, 2008). Walter Sosa Escudero and Anil K. Bera. "Tests for Unbalanced Error Component Models Under Local Misspecication".

- Nro. 64 (Febrero, 2008). Luis Casanova. "Trampas de Pobreza en Argentina: Evidencia Empírica a Partir de un Pseudo Panel".

- Nro. 63 (Enero, 2008). Francisco Franchetti y Diego Battistón. "Inequality in Health Coverage, Empirical Analysis with Microdata for Argentina 2006".

- Nro. 62 (Diciembre, 2007). Adriana Conconi, Guillermo Cruces, Sergio Olivieri y Raúl Sánchez. "E pur si muove? Movilidad, Pobreza y Desigualdad en América Latina". 
- Nro. 61 (Diciembre, 2007). Mariana Marchionni, Germán Bet y Ana Pacheco. "Empleo, Educación y Entorno Social de los Jóvenes: Una Nueva Fuente de Información".

- Nro. 60 (Noviembre, 2007). María Gabriela Farfán y María Florencia Ruiz Díaz. "Discriminación Salarial en la Argentina: Un Análisis Distributivo".

- Nro. 59 (Octubre, 2007). Leopoldo Tornarolli y Adriana Conconi. "Informalidad y Movilidad Laboral: Un Análisis Empírico para Argentina".

- Nro. 58 (Septiembre, 2007). Leopoldo Tornarolli. "Metodología para el Análisis de la Pobreza Rural".

- Nro. 57 (Agosto, 2007). Adriana Conconi y Andrés Ham. "Pobreza Multidimensional Relativa: Una Aplicación a la Argentina".

- Nro. 56 (Agosto, 2007). Martín Cicowiez, Luciano Di Gresia y Leonardo Gasparini. "Politicas Públicas y Objetivos de Desarrollo del Milenio en la Argentina".

- Nro. 55 (Julio, 2007). Leonardo Gasparini, Javier Alejo, Francisco Haimovich, Sergio Olivieri y Leopoldo Tornarolli. "Poverty among the Elderly in Latin America and the Caribbean".

- Nro. 54 (Julio, 2007). Gustavo Javier Canavire-Bacarreza y Luís Fernando Lima Soria. "Unemployment Duration and Labor Mobility in Argentina: A Socioeconomic-Based Pre- and Post-Crisis Analysis".

- Nro. 53 (Junio, 2007). Leonardo Gasparini, Francisco Haimovich y Sergio Olivieri. "Labor Informality Effects of a Poverty-Alleviation Program".

- Nro. 52 (Junio, 2007). Nicolás Epele y Victoria Dowbley. "Análisis Ex-Ante de un Aumento en la Dotación de Capital Humano: El Caso del Plan Familias de Transferencias Condicionadas".

- Nro. 51 (Mayo, 2007). Jerónimo Carballo y María Bongiorno. "Vulnerabilidad Individual: Evolución, Diferencias Regionales e Impacto de la Crisis. Argentina 1995 - 2005".

- Nro. 50 (Mayo, 2007). Paula Giovagnoli. "Failures in School Progression".

- Nro. 49 (Abril, 2007). Sebastian Galiani, Daniel Heymann, Carlos Dabús y Fernando Tohmé. "Land-Rich Economies, Education and Economic Development".

- Nro. 48 (Abril, 2007). Ricardo Bebczuk y Francisco Haimovich. "MDGs and Microcredit: An Empirical Evaluation for Latin American Countries".

- Nro. 47 (Marzo, 2007). Sebastian Galiani y Federico Weinschelbaum. "Modeling Informality Formally: Households and Firms". 
- Nro. 46 (Febrero, 2007). Leonardo Gasparini y Leopoldo Tornarolli. "Labor Informality in Latin America and the Caribbean: Patterns and Trends from Household Survey Microdata".

- Nro. 45 (Enero, 2007). Georgina Pizzolitto. "Curvas de Engel de Alimentos, Preferencias Heterogéneas y Características Demográficas de los Hogares: Estimaciones para Argentina".

- Nro. 44 (Diciembre, 2006). Rafael Di Tella, Sebastian Galiani y Ernesto Schargrodsky. "Crime Distribution and Victim Behavior during a Crime Wave".

- Nro. 43 (Noviembre, 2006). Martín Cicowiez, Leonardo Gasparini, Federico Gutiérrez y Leopoldo Tornarolli. "Areas Rurales y Objetivos de Desarrollo del Milenio en America Latina y El Caribe".

- Nro. 42 (Octubre, 2006). Martín Guzmán y Ezequiel Molina. "Desigualdad e Instituciones en una Dimensión Intertemporal".

- Nro. 41 (Septiembre, 2006). Leonardo Gasparini y Ezequiel Molina. "Income Distribution, Institutions and Conflicts: An Exploratory Analysis for Latin America and the Caribbean".

- Nro. 40 (Agosto, 2006). Leonardo Lucchetti. "Caracterización de la Percepción del Bienestar y Cálculo de la Línea de Pobreza Subjetiva en Argentina".

- Nro. 39 (Julio, 2006). Héctor Zacaria y Juan Ignacio Zoloa. "Desigualdad y Pobreza entre las Regiones Argentinas: Un Análisis de Microdescomposiciones".

- Nro. 38 (Julio, 2006). Leonardo Gasparini, Matías Horenstein y Sergio Olivieri. "Economic Polarisation in Latin America and the Caribbean: What do Household Surveys Tell Us?".

- Nro. 37 (Junio, 2006). Walter Sosa-Escudero, Mariana Marchionni y Omar Arias. "Sources of Income Persistence: Evidence from Rural El Salvador".

- Nro. 36 (Mayo, 2006). Javier Alejo. "Desigualdad Salarial en el Gran Buenos Aires: Una Aplicación de Regresión por Cuantiles en Microdescomposiciones".

- Nro. 35 (Abril, 2006). Jerónimo Carballo y María Bongiorno. "La Evolución de la Pobreza en Argentina: Crónica, Transitoria, Diferencias Regionales y Determinantes (1995-2003)".

- Nro. 34 (Marzo, 2006). Francisco Haimovich, Hernán Winkler y Leonardo Gasparini. "Distribución del Ingreso en América Latina: Explorando las Diferencias entre Países".

- Nro. 33 (Febrero, 2006). Nicolás Parlamento y Ernesto Salinardi. "Explicando los Cambios en la Desigualdad: Son Estadísticamente Significativas las Microsimulaciones? Una Aplicación para el Gran Buenos Aires". 
- Nro. 32 (Enero, 2006). Rodrigo González. "Distribución de la Prima Salarial del Sector Público en Argentina".

- Nro. 31 (Enero, 2006). Luis Casanova. "Análisis estático y dinámico de la pobreza en Argentina: Evidencia Empírica para el Periodo 1998-2002".

- Nro. 30 (Diciembre, 2005). Leonardo Gasparini, Federico Gutiérrez y Leopoldo Tornarolli. "Growth and Income Poverty in Latin America and the Caribbean: Evidence from Household Surveys".

- Nro. 29 (Noviembre, 2005). Mariana Marchionni. "Labor Participation and Earnings for Young Women in Argentina".

- Nro. 28 (Octubre, 2005). Martín Tetaz. "Educación y Mercado de Trabajo".

- Nro. 27 (Septiembre, 2005). Matías Busso, Martín Cicowiez y Leonardo Gasparini. "Ethnicity and the Millennium Development Goals in Latin America and the Caribbean".

- Nro. 26 (Agosto, 2005). Hernán Winkler. "Monitoring the Socio-Economic Conditions in Uruguay".

- Nro. 25 (Julio, 2005). Leonardo Gasparini, Federico Gutiérrez y Guido G. Porto. "Trade and Labor Outcomes in Latin America's Rural Areas: A Cross-Household Surveys Approach".

- Nro. 24 (Junio, 2005). Francisco Haimovich y Hernán Winkler. "Pobreza Rural y Urbana en Argentina: Un Análisis de Descomposiciones".

- Nro. 23 (Mayo, 2005). Leonardo Gasparini y Martín Cicowiez. "Equality of Opportunity and Optimal Cash and In-Kind Policies".

- Nro. 22 (Abril, 2005). Leonardo Gasparini y Santiago Pinto. "Equality of Opportunity and Optimal Cash and In-Kind Policies".

- Nro. 21 (Abril, 2005). Matías Busso, Federico Cerimedo y Martín Cicowiez. "Pobreza, Crecimiento y Desigualdad: Descifrando la Última Década en Argentina".

- Nro. 20 (Marzo, 2005). Georgina Pizzolitto. "Poverty and Inequality in Chile: Methodological Issues and a Literature Review".

- Nro. 19 (Marzo, 2005). Paula Giovagnoli, Georgina Pizzolitto y Julieta Trías. "Monitoring the Socio-Economic Conditions in Chile".

- Nro. 18 (Febrero, 2005). Leonardo Gasparini. "Assessing Benefit-Incidence Results Using Decompositions: The Case of Health Policy in Argentina".

- Nro. 17 (Enero, 2005). Leonardo Gasparini. "Protección Social y Empleo en América Latina: Estudio sobre la Base de Encuestas de Hogares". 
- Nro. 16 (Diciembre, 2004). Evelyn Vezza. "Poder de Mercado en las Profesiones Autorreguladas: El Desempeño Médico en Argentina".

- Nro. 15 (Noviembre, 2004). Matías Horenstein y Sergio Olivieri. "Polarización del Ingreso en la Argentina: Teoría y Aplicación de la Polarización Pura del Ingreso".

- Nro. 14 (Octubre, 2004). Leonardo Gasparini y Walter Sosa Escudero. "Implicit Rents from Own-Housing and Income Distribution: Econometric Estimates for Greater Buenos Aires".

- Nro. 13 (Septiembre, 2004). Monserrat Bustelo. "Caracterización de los Cambios en la Desigualdad y la Pobreza en Argentina Haciendo Uso de Técnicas de Descomposiciones Microeconometricas (1992-2001)".

- Nro. 12 (Agosto, 2004). Leonardo Gasparini, Martín Cicowiez, Federico Gutiérrez y Mariana Marchionni. "Simulating Income Distribution Changes in Bolivia: a Microeconometric Approach".

- Nro. 11 (Julio, 2004). Federico H. Gutierrez. "Dinámica Salarial y Ocupacional: Análisis de Panel para Argentina 1998-2002".

- Nro. 10 (Junio, 2004). María Victoria Fazio. "Incidencia de las Horas Trabajadas en el Rendimiento Académico de Estudiantes Universitarios Argentinos".

- Nro. 9 (Mayo, 2004). Julieta Trías. "Determinantes de la Utilización de los Servicios de Salud: El Caso de los Niños en la Argentina".

- Nro. 8 (Abril, 2004). Federico Cerimedo. "Duración del Desempleo y Ciclo Económico en la Argentina".

- Nro. 7 (Marzo, 2004). Monserrat Bustelo y Leonardo Lucchetti. "La Pobreza en Argentina: Perfil, Evolución y Determinantes Profundos (1996, 1998 Y 2001)".

- Nro. 6 (Febrero, 2004). Hernán Winkler. "Estructura de Edades de la Fuerza Laboral y Distribución del Ingreso: Un Análisis Empírico para la Argentina".

- Nro. 5 (Enero, 2004). Pablo Acosta y Leonardo Gasparini. "Capital Accumulation, Trade Liberalization and Rising Wage Inequality: The Case of Argentina".

- Nro. 4 (Diciembre, 2003). Mariana Marchionni y Leonardo Gasparini. "Tracing Out the Effects of Demographic Changes on the Income Distribution. The Case of Greater Buenos Aires".

- Nro. 3 (Noviembre, 2003). Martín Cicowiez. "Comercio y Desigualdad Salarial en Argentina: Un Enfoque de Equilibrio General Computado".

- Nro. 2 (Octubre, 2003). Leonardo Gasparini. "Income Inequality in Latin America and the Caribbean: Evidence from Household Surveys".

- Nro. 1 (Septiembre, 2003). Leonardo Gasparini. "Argentina's Distributional Failure: The Role of Integration and Public Policies". 
